\title{
Arte Vida: itinerários de arte indígena nas cidades contemporâneas
}

Ana Elisa de Castro Freitas ${ }^{1}$

\section{Resumo}

A presença indígena nas cidades é fenômeno próprio da gênese urbana nas Américas. Paradoxalmente, índio e cidade se apresentam como linhas de fuga que deslizam para direções diametralmente opostas no imaginário urbano colonial, evocando a ideia de corpos fora de lugar. Tal paradoxo tem origem em políticas coloniais-estatais indutoras de regimes de alienação, redução territorial e aldeamento indígena, motivando forças sociais de invisibilização, negação, marginalização e gentrificação, que incidem sistematicamente sobre os modos de vida indígena no urbano. Esse processo é reconfigurado pelas tendências de aceleração, virtualização e globalização das relações sociais nas cidades contemporâneas, exigindo um olhar que possibilite rever a cidade desde as perspectivas das subjetividades e alteridades que nela habitam. Neste artigo, proponho pensar a cidade contemporânea focalizando itinerários de arte indígena instalados e desinstalados cotidianamente por coletividades ameríndias em ruas, praças, florestas e galerias de arte, e seus desdobramentos sociopolíticos e ambientais. Tais instalações evocam ecologias desviantes dos padrões urbanos hegemônicos, marcados pelas retas e ângulos da planificação diretora das cidades, sendo compreendidas como emanações poéticas da vida ameríndia. 0 foco da análise revela, de um lado, itinerários de fabricação e circulação de formas tridimensionais de cipó trançado, deslocadas das florestas e instaladas nas ruas da cidade de Porto Alegre por coletividades Kaingang e, de outro, a ativação de circuitos de arte indígena contemporânea em cidades como Brasília, São Paulo, Londrina, Curitiba, Porto Alegre, Boa Vista, Belo Horizonte, e seus deslocamentos através de museus, universidades, ruas e redes sociais. Os fluxos de materiais e forças mobilizados pelos itinerários de arte indígena na cidade evocam uma trama rizomática, incidência da vida sobre tendências de redução, territorialização e gentrificação, poética que reivindica 0 acesso indígena à cidade e amplia o horizonte de possibilidades para o urbano na contemporaneidade.

\section{Palavras-chave}

Arte Indígena Contemporânea. Cidade. Ecologia Urbana. Antropologia da Imagem.

\section{Abstract}

The indigenous presence in the cities is a phenomenon typical of the urban genesis in the Americas. Paradoxically, indigenous people and the city appear as escape paths that slide in diametrically

${ }^{1}$ Doutora em Antropologia Social pela UFRGS. E-mail: anaelisa.freitas.ufpr@gmail.com. 
opposite directions in the colonial urban imagination, evoking the idea of bodies out of place. This paradox originates from colonial-state policies that induce alienation, territorial reduction and indigenous settlement regimes, motivating social forces of invisibility, alienation, marginalization and gentrification, which systematically affect indigenous ways of life in urban areas. This process is reconfigured by the trends of acceleration, virtualization and globalization of social relations in contemporary cities, demanding a point of view that makes it possible to resee the city from the perspectives of the subjectivities and otherness that inhabit it. In this article, I propose to think about the contemporary city focusing on itineraries of indigenous art installed and uninstalled daily by Amerindian collectives in streets, squares, forests and art galleries, and their sociopolitical and environmental developments. Such installations evoke ecologies deviating from hegemonic urban patterns, marked by the straight lines and angles of city planning, being understood as poetic emanations of the Amerindian life. The focus of analysis reveals, on one hand, itineraries for the manufacture and circulation of three-dimensional forms of twisted vines, displaced from the forests and installed in the streets of Porto Alegre city by Kaingang collectives and, on the other, the activation of contemporary indigenous art circuits in cities like Brasília, São Paulo, Londrina, Curitiba, Porto Alegre, Boa Vista, Belo Horizonte and their travels around the world through museums, universities, streets and social networks. The flows of materials and forces mobilized by the itineraries of indigenous art in the cities evoke a rhizomatic plot, the incidence of life on trends of reduction, territorialization and gentrification, a poetics that claims indigenous access to the city and expands the horizon of possibilities for the urban in contemporary times.

\section{Keywords}

Contemporary Indigenous Art. City. Urban Ecology. Anthropology of Image.

\section{Itinerância}

Numa perspectiva européia, as coisas se apresentavam assim: na Idade Média, e até o início do século XIX, o desenvolvimento da técnica em todas as produções artesanais caminhava muito mais lentamente do que na arte. A arte podia levar o tempo que quisesse para brincar com os procedimentos técnicos de vários modos. A mudança iniciada por volta de 1800 impôs um ritmo à arte, e quanto mais acelerado se tornava este ritmo, mais a moda avançava em todos os domínios. Finalmente, chegouse ao estado de coisas atual: torna-se plausível a possibilidade de a arte não encontrar mais tempo de inserir-se de algum modo no processo técnico. O reclame é a astúcia com a qual o sonho se impõe à indústria. (BENJAMIN, 2009, p. 206). 
A publicação em 2006 da tradução integral das Passagens, de Walter Benjamin, apresentou em língua portuguesa uma instigante crítica ao projeto de "modernização" de Paris no século XIX, na qual o autor transpassa as muitas galerias entreabertas na reforma urbana coordenada pelo Barão Haussmann. A proposição metodológica de Benjamin, dando continuidade ao livro sobre o drama barroco alemão, ressurge no modo de construção do texto das Passagens, em que a noção de constelação entrelaça um pensamento fragmentado e fragmentário em passagens próprias e alheias e que repõe a crítica cultural (no sentido benjaminiamo de delimitação, dos limites) em um dado espaço e tempo.

A proposta de seguir itinerários de arte indígena em cidades contemporâneas e de compreender a cidade a partir desses itinerários é motivada pela perspectiva metodológica benjaminiana do percurso, que orienta a escrita das Passagens (BENJAMIN, 2009). Como bem sinalizam Solange Jobim e Souza e Sonia Kramer (2009, p.7), tal perspectiva exige “(...) deixar o corpo e o pensamento buscarem seus próprios contornos na vida, no cotidiano das trocas sociais e, a partir desta experiência imediata com a realidade, dar forma e conteúdo aos acontecimentos que retratam uma época".

No entanto, diferentemente da Paris do século XIX, retratada nas Passagens, aqui há a exigência de ajustar as lentes para cidades nas quais sequer os ideais de modernidade se revelam plenos, pelo contrário, estão perpassados por relações coloniais, com seus privilégios, prebendas e assimetrias de poder, ainda que tensionados por forças de cosmopolitismo e globalização.

A opção metodológica pelos itinerários, inspirada no materialismo de Walter Benjamin, convoca um olhar atento ao mundo, suas contradições, conflitos e dissonâncias, sem entretanto limitar-se a elas. A partir da experiência imediata da realidade, é necessário liberar a palavra das amarras de um devir-conceito permitindo-se ir junto com as imagens que derivam da experiência, para então assumir as tarefas da tradução e da narração (BENJAMIN, 2011; 2012).

Na composição do presente artigo busco captar a proposição hermenêutica e dialética de Walter Benjamin, adotando a perspectiva de um pensamento caminhante (GROS, 2011), e alinhadas as lentes aos movimentos de itinerância dos povos indígenas através de Abya Yala². Inspirada na fluidez resiliente do

${ }^{2}$ De acordo com Carlos Walter Porto-Gonçalves (2006), o termo Abya Yala é sinônimo de América na língua do povo Kuna. Sua tradução evoca os significados de "Terra madura", "Terra Viva" ou "Terra em florescimento". Na contemporaneidade, diversos povos originários do continente têm adotado o termo Abya Yala para demarcar sua autodesignação relacionada a um sentimento de 
Oguatá Porã, belo caminhar Guarani (FREITAS, 2016), lanço e reconheço meu corpo no corpo da cidade para reencontrar os rastros, pontos e traços, notas e registros de duas décadas de pesquisa compartilhada com coletividades indígenas no urbano.

A materialidade da experiência se mostra como um tecido atravessado por feixes de imagens, cuja paleta de cores e tons evoca uma constelação de acontecimentos. Sem compromisso com a linearidade histórica, as memórias narradas por meus interlocutores indígenas evocam o terror dos conflitos entre o universo de seus grupos étnicos e os ordenamentos tutelares restritivos do Estado $^{3}$, emergindo como ruínas que se erguem em escombros até o céu, sem entretanto tocá-lo (KRENAK, 2019). Como num clarão, as imagens de um passado colonial violento se refazem no cotidiano de luta pelo direito à cidade ${ }^{4}$ (LEFEBVRE, 2011), nos corredores do expediente administrativo, no paço municipal, no enfrentamento dos agentes públicos nas feiras e ruas da cidade: - Levanta já esse balaio! Está vendo esse meio fio? Daí para lá, nem um metro a mais!

unidade e pertencimento, em contraste ao termo América.

${ }^{3}$ Fantasma da Integração: a Lei Federal 6.001, de 19 de dezembro de 1973 - Estatuto do Índio permanece vigente no Brasil. Em seu artigo $4^{\circ}$, classifica os índios em "isolados, em vias de integração ou integrados à sociedade nacional", tipologias assimilacionistas orientadas pelo paradigma da mistura racial e redução das alteridades indígenas aos desígnios da nação. Ao longo de trinta anos os povos indígenas reivindicam, sem êxito, a revogação desse Estatuto, à luz do reconhecimento dos direitos expressos no Capítulo VIII e outros da Constituição Federal de 1988, que reconhece aos índios o direito de viver conforme suas orientações culturais e sociopolíticas, nas terras que tradicionalmente ocupam (artigo 231), representando diretamente suas deliberações como sujeitos de seus direitos perante ao Estado (artigo 232).

${ }^{4}$ A formulação de um direito humano à cidade encontra suas primeiras expressões na década de 1960 com a aceleração do processo de urbanização em curso em diversos países do mundo. Tratase de uma nova geração de direitos, de caráter difuso, nos quais se busca consolidar o acesso equitativo à cidade a partir de políticas públicas que promovam a redução das desigualdades e avancem nas agendas de justiça social. As formulações propostas desde Henri Lefebvre (2011) ecoam nas agendas internacionais contemporâneas sobre as cidades e no ordenamento jurídico recepcionado, por exemplo, no Estatuto da Cidade (Lei Federal n. 10.257, de 10 de julho de 2001). 


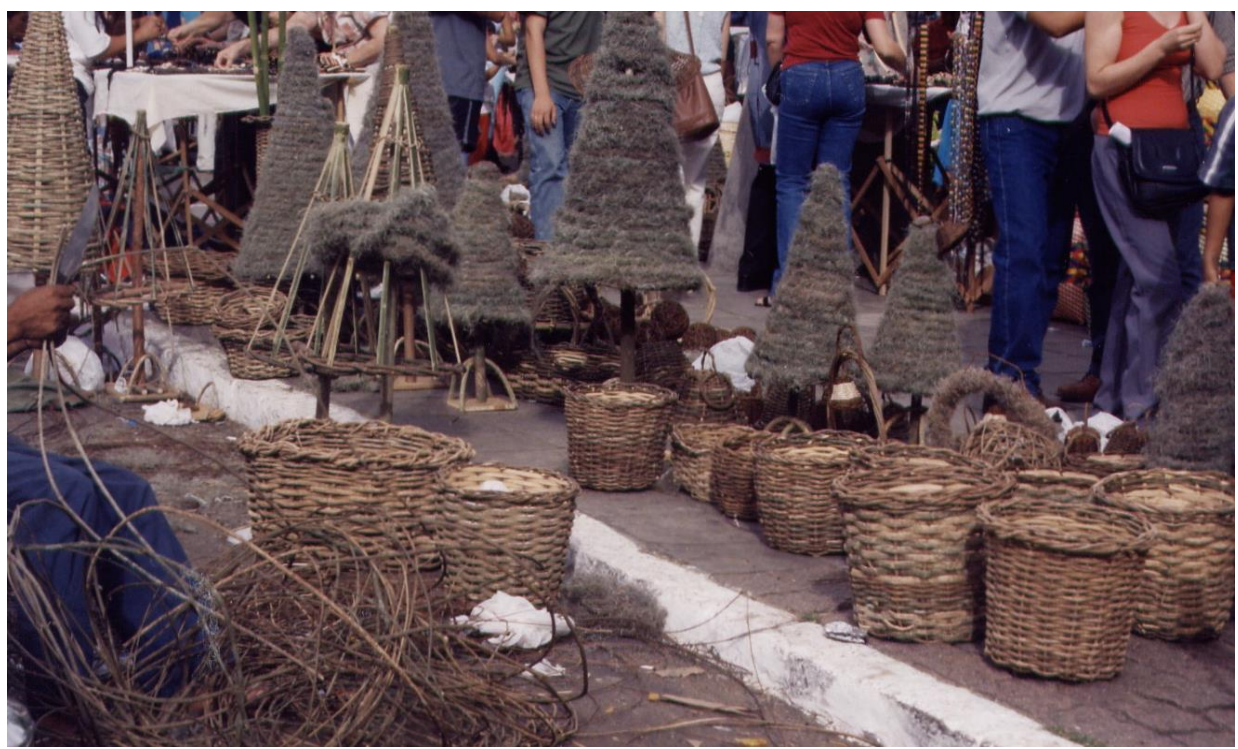

Imagem 1 - Instalação de arte Kaingang de cipó trançado na rua José Bonifácio. Feira do Bric do

Parque da Redenção. Porto Alegre, 2003. (Foto da autora).

Em sua nona tese "Sobre o Conceito de História", Benjamin encontra na fantasmagoria que sobrevive, habita e movimenta a obra de arte (WARBURG, 2015) as imagens que lhe fornecem a chave para o entendimento da dimensão catastrófica da passagem do tempo no Ocidente. Trata-se de Angelus Novus (1920), desenho de Paul Klee, que acompanhou Benjamin até sua morte. Esse ser de "olhos escancarados, queixo caído e asas abertas" lhe inspira "um anjo que parece estar na iminência de se afastar de algo que ele encara fixamente". Para Benjamin, esse seria o aspecto do "anjo da história":

Seu semblante está voltado para o passado. Onde nós vemos uma cadeia de acontecimentos, ele vê uma catástrofe única, que acumula incansavelmente ruína sobre ruína e as arremessa a seus pés. Ele gostaria de deter-se para acordar os mortos e juntar os fragmentos. Mas uma tempestade sopra do paraíso e prende-se em suas asas com tanta força que o anjo não pode mais fechá-las. Essa tempestade o impele irresistivelmente para o futuro, ao qual ele volta as costas, enquanto o amontoado de ruínas diante dele cresce até o céu. É essa tempestade que chamamos progresso (BENJAMIN, 2012, p. 245-246). 


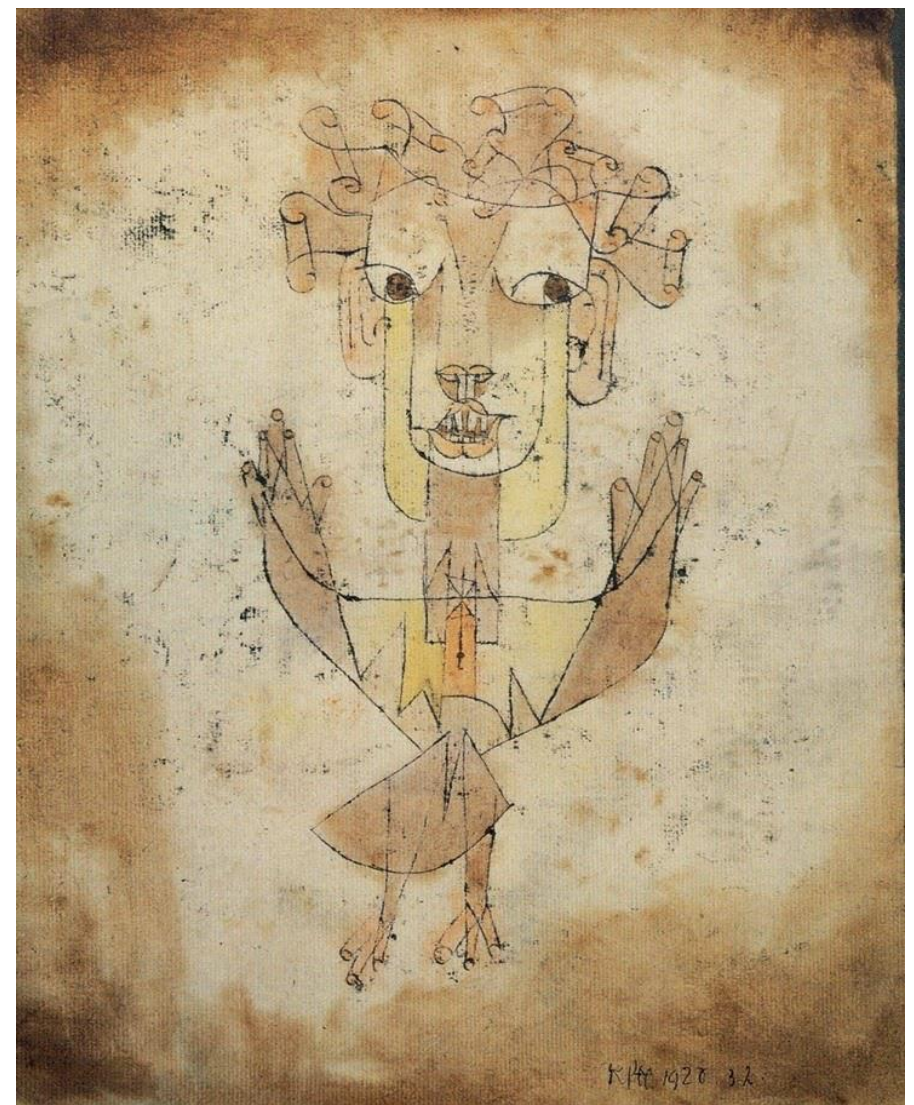

Imagem 2 - Angelus Novus. 31,8 x 24,2cm. Paul Klee (1920). Nanquim e pastel aquarelado sobre papel. Acervo do Museu de Israel, Jerusalem.

Imagem dialética, o espectro da violência colonial se entrelaça na experiência indígena nas cidades contemporâneas, revivida nos constrangimentos do ordenamento público, mas reposicionada cotidianamente por outras imagens. Igualmente dialéticas, tais imagens evocam a territorialidade livre no andar pelos becos, ruas, campos e bosques das cidades, interligando - pés descalços - asfalto e floresta, numa ecologia profunda da qual participam terra, águas, gentes, plantas, paisagens e espíritos, tecendo a teia de uma cosmopólis que se materializa numa diversidade extraordinária de instalações artísticas no urbano ${ }^{5}$ (FREITAS, 2005).

${ }^{5}$ O percurso metodológico do conceito de instalação artística define-se no contexto da arte contemporânea, no âmbito de projetos e obras que aproximam arte e ambiente, artista e espectador. No Brasil, entre as décadas de 1950 e 1980, as obras e projetos artísticos de Lygia Clark e Hélio Oiticica rompem radicalmente com a concepção de uma arte estetizada e alienada da vida social, 


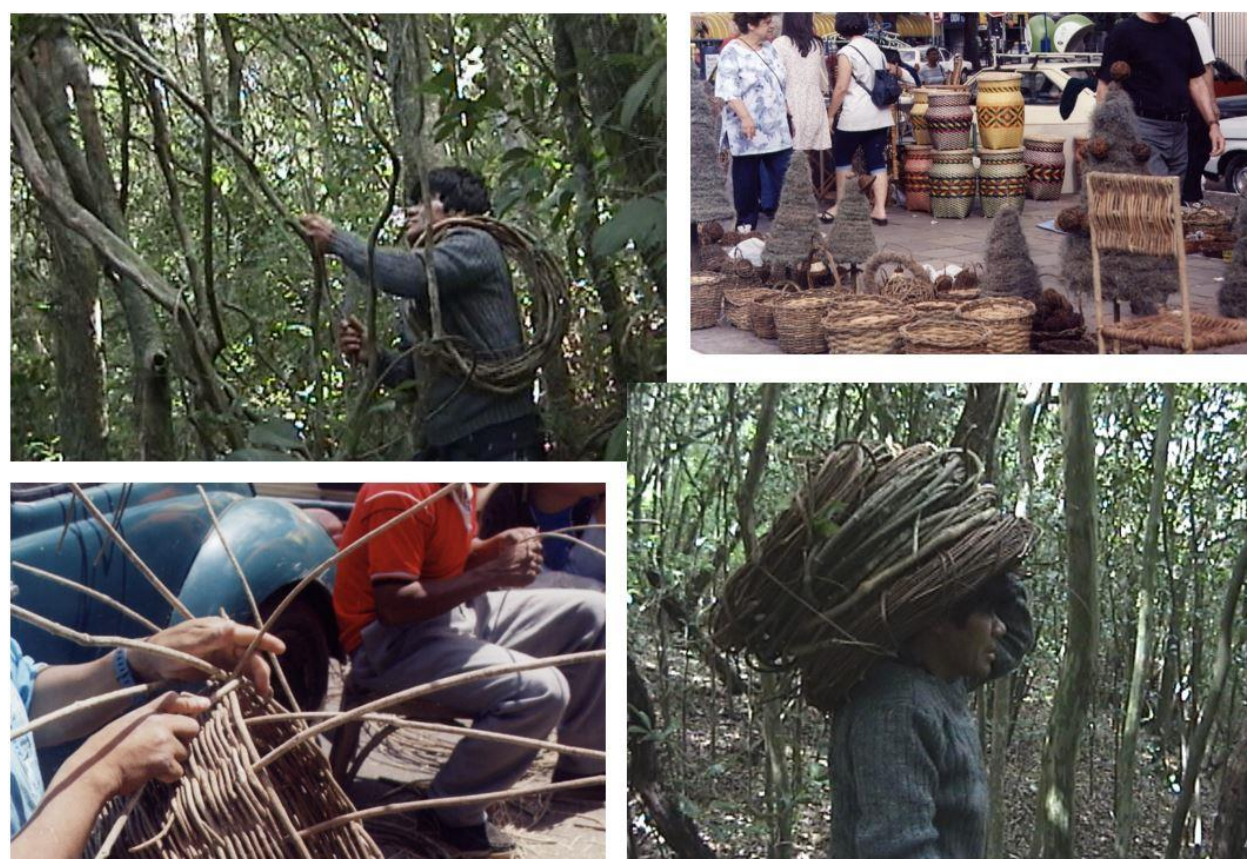

Imagem 3 - Mrur Jykre - a cultura do cipó. Tudo acontece na cidade de Porto Alegre: Francisco

Rokàg dos Santos desloca cipó das florestas urbanas para o asfalto, transforma as fibras em arte e instala nas feiras e ruas da cidade (Colagem de fotos da autora).

Atenta a essa direção, a escrita de inspiração benjaminiana busca ela própria um percurso itinerante: desdobra-se a partir do encontro com fragmentos de notas de campo, esboços, obras de arte e fotografias, que se apresentam também como ruínas em permanente reconstrução, sem restringirse a um devir formal que estanque o fluxo das imagens na experiência narrativa. Mais do que a forma acabada, como propôs Paul Klee, interessa o "dar forma", mantendo o fluxo que a torna visível (KLEE, 1961, p. 76 apud INGOLD, 2012, p. 26).

reinscrevendo-a no ambiente, na experiência sensorial, embaralhando os papéis de artista e espectador, interseccionando o espaço artístico com o espaço público. Para um aprofundamento dos sentidos do conceito de instalação artística na arte contemporânea, ver, por exemplo, Mário Pedrosa (1981); Marília Andrés Ribeiro (1998); Paulo Renato Damé (2007); Luciana Bosco e Silva (2009). Para as interfaces entre arte indígena e arte contemporânea no Brasil, ver, por exemplo, Damiana Bregalda (2017b). Para os sentidos que o termo vem assumindo na arte indígena contemporânea, ver o conjunto da obra e o debate formulado por Jaider Esbell (http://www.jaideresbell.com.br). 


\section{A Árvore da Vida}

Definitivamente não somos iguais, e é maravilhoso saber que cada um de nós que está aqui é diferente do outro, como constelações. O fato de podermos compartilhar esse espaço, de estarmos juntos viajando não significa que somos iguais; significa exatamente que somos capazes de atrair uns aos outros pelas nossas diferenças, que deveriam guiar o nosso roteiro de vida. (Krenak, 2019, p.33).

Ao transpassar as Américas, o anjo da história captou que o ideal de progresso por essas terras constituía um espelho invertido na negação do Outro, desde a imagem do vazio demográfico. As extensas terras, águas, planícies e montanhas deveriam, a partir dessa perspectiva alóctone, ser povoadas, colonizadas, urbanizadas. Em nome do ideal de vazio demográfico, a tempestade do progresso alargou seus braços desde as costas litorâneas, do Atlântico ao Pacífico, atravessando sertões e veredas, deixando em seu rastro as ruínas de extermínio e negação do Outro. Ideias, instituições e concepções de mundo foram importadas e, pela força, impostas.

Regimes de redução sociopolítica e territorial se espalharam pelo continente assumindo contornos tutelares, sobretudo na América portuguesa (e.g. SOUZA LIMA, 1987; OLIVEIRA, 1998). Uma ideologia de mistura racial, integração e assimilação, orientada por um ideal eurocêntrico de branqueamento, induziu agentes luso-brasileiros na empresa do domínio territorial e fixação de vilas, cidades e aldeias, aliada a uma narrativa oficial do desaparecimento gradual dos índios (categoria heteronômica e redutora que condensou uma diversidade de povos) na geléia geral do povo brasileiro (RIBEIRO, 1995).

Reduzidas a índios e invisibilizadas sob o manto de dominus, alteridades autóctones viveram políticas de confinamento em aldeias, áreas nas quais, entre as décadas de 1940 e 1970, foram submetidas pelo Estado a uma história indigenista de violência, abuso, trabalho forçado, tortura e terror6. Classificados em isolados, integrados ou em vias de integração, em meados do século XX, os indios praticamente desapareceram das notícias e jornais que circulavam nas grandes cidades brasileiras, sendo substituídos por tipos

${ }^{6}$ O Relatório Figueiredo (1967), com mais de 7.000 páginas, registra o terror implantado por funcionários públicos vinculados ao Serviço de Proteção aos Índios contra a pessoa indígena entre as décadas de 1940 e 1970, em todo o país. Confinamento, estupro, tortura e trabalho forçado nas aldeias, com impacto maior sobre a mulheres, eram complementados por políticas de remoção e reintegração de pessoas e grupos aos limites delimitados pelo Estado (BRASIL, 1967). 
caricatos e genéricos, considerados misturados, extintos ou fora de lugar. Uma gama variada de objetos de arte produzidos pelos povos indígenas foi removida de seus sistemas culturais e contextos de produção e circulação para integrar coleções etnográficas em universidades e museus e suas reservas técnicas, em todo o mundo.

Mesmo sob os escombros das ruínas dessa história colonial, os habitantes de Abya Yala não se deixam sufocar. As duas últimas décadas do século XX assinalam a ressignificação positiva das identidades indígenas em processos de reemergência étnica (OLIVEIRA, 1998b) 7 . Pessoas e coletivos pertencentes aos mais diversos povos passam a visualizar na categoria índio uma "síntese com força de afirmação no jogo de espelho das diferenças", fortalecendo um nível de "experiência histórica compartilhada" (FREITAS, 2016b, p.47). Participam ativamente na cena política nacional, fenômeno que acompanha a crescente organização dos movimentos sociais indígenas ao longo de toda a América (e.g. CARDOSO DE OLIVEIRA, R.; CARDOSO DE OLIVEIRA, L.R. 1996; CARDOSO DE OLIVEIRA, 2006; LUCIANO, 2006).

A luta por reconhecimento territorial e demarcação de terras indígenas reverbera nas cidades. As vozes e corpos indígenas participam do cotidiano urbano atuando nas lutas por direitos sociais e bens comuns e nas agendas de fóruns internacionais. Esse processo desdobra-se em demanda por políticas públicas específicas de atenção à saúde dos povos, educação escolar indígena, assistência social diferenciada (e.g. CARNEIRO DA CUNHA; BARBOSA, 2018; FAJARDO, 2011; FREITAS; HARDER, 2018). A revitalização das línguas indígenas, as manifestações culturais e a arte indígena ingressam na performance das lutas dos povos, conjugando arte e política e colaborando na conquista de um conjunto de políticas públicas que avançam, embora de modo tímido e com retrocessos, na afirmação de suas especificidades ${ }^{8}$.

Os dados censitários oficiais de 2010 apontam que as territorialidades indígenas passaram a incluir de modo significativo as cidades brasileiras, que

\footnotetext{
7 O estudo de João Pacheco de Oliveira (1998b, p. 47) é pioneiro na exposição dessa problemática no Brasil. Ele observa que, na década de 1950, os registros oficiais de povos indígenas no Nordeste incluiam uma lista de 10 etnias. Quarenta anos depois, em 1994, as mesmas fontes mencionavam 23 etnias indígenas na mesma região, indicando, como observa o autor, "o surgimento recente (duas décadas!) de povos que são pensados, e se pensam, como originários". Tal processo, interpretado à luz das teorias da etnicidade, revela um tempo histórico de re-emergência das alteridades indígenas, por entre os escombros das ruínas coloniais.

${ }^{8}$ Um evento emblemático para uma história da arte indígena contemporânea remete à performance de Ailton Krenak pintando o rosto com jenipapo durante a Assembléia Nacional Constituínte de 1988 (e.g. BREGALDA, 2017).
} 
historicamente foram assentadas sobre parcelas de seus territórios (TOMMASINO, 1995), sem que isso significasse a negação de suas territorialidades e alteridades. Ao contrário, pessoas e coletivos indígenas passam a fazer parte do cotidiano urbano não como indios integrados ou assimilados, mas como Kaingang, Guarani, Krenak, Macuxi, Tukano, Terena, Wapichana, Pankararu, Huni Kuins e muitos mais. Esse reposicionamento tem implicado uma série de processos locais que incluem o ingresso de jovens indígenas no ensino superior, o estabelecimento de áreas indígenas nas cidades em todo o país, a participação de pessoas e coletivos indígenas em eventos, a articulação de redes interculturais e projetos colaborativos entre coletivos indígenas e museus, universidades, etc. (e.g. BAINES, 2001; FREITAS, 2005; FREITAS; FAGUNDES, 2008; BREGALDA, 2012, 2017, 2017b; SAMPAIO, 2017; ALBINO, 2019).

A Árvore da Vida - imagem alegórica que evoca inúmeras narrativas mitopoéticas ameríndias da fertilidade que remetem ao mundo vegetal em toda a Abya Yala - jamais secou, irrigada abundantemente pela re-existência ao longo dos tempos, numa ontologia do estar aqui ${ }^{9}$. As poéticas ameríndias de andar sobre a terra conectando florestas, campos e cidades e atravessando uma diversidade de ecossistemas e regiões se expressa em ecologias desviantes, cujas relações com as paisagens, ambientes e seres que nelas vivem se materializam na transformação diuturna de materiais variados (fibras, penas, garras, dentes, frutos, sementes, missangas, contas, fios, panos, tintas, telas) em uma infinidade de formas tridimensionais que transpõem fronteiras utilitárias, carregando uma densidade de significados e complexidade de ideias (DIAS, 2000). Trata-se de narrativas ou econarrativas, cosmopoéticas ou cosmopolíticas, cestos-textos, telas-manifestos, que dilatam as possibilidades de ser e estar no mundo, de ler e viver a cidade e reinventar a arte.

\footnotetext{
${ }^{9}$ Rodolfo Kusch (1989) concebeu a América como um continente dividido entre as intimações da barbárie e da civilização, da natureza e da ficção urbana. Nessa América partida, a ideia de mestiçagem se apresenta como promessa de uma conciliação inatingível diante das desigualdades sociais forjadas por uma história violenta, marcada por tensões e cisões coloniais. Tal imaginário de mestiçagem, sempre que reduzido à ideia de mistura, se revela espelho da incorporação e anulação do Outro, justificando a barbárie dos empreendimentos geopolíticos de unificação nacional e delimitação de fronteiras, desdobrando-se em ordenamentos territoriais que fundam ideias coloniais de índio, aldeia, povo, cidade enquanto totalidades opostas, arbitrárias e que ocultam dissonâncias internas a seus modelos explicativos. Alternativamente, Kusch propõe que a América só pode resgatar a si mesma descompassando a razão colonial através de uma radical imersão telúrica, nas entranhas da terra, reativando as forças imaginantes capazes de despertar uma mirada desde aqui (KUSCH, 1989, p. 22; FREITAS, 2005, p. 49).
} 
A segregação aristotélica entre sujeito e objeto, vigente no campo do conhecimento validado pelas Epistemologias do Norte (SANTOS, 2019), se constituiu uma barreira outrora intransponível às concepções de mundo que habitam o Sul global, reificando fronteiras e ruínas e separando Nós e os Outros (TODOROV, 1993). Da mesma maneira, natureza e cultura se mostram artefatos insuficientes para expressar a intensidade das relações intersubjetivas e socioambientais tramadas na complexa teia do viver e criar perspectiva ameríndio, que tampouco distingue razão de transcendência (VIVEIROS DE CASTRO, 1996).

A transposição desses limites epistemológicos é realizada não sem muitos tropeços e, ao mesmo tempo, recuos. Para além de uma fundação da antropologia a partir dos cânones coloniais do início do século passado, os percursos e itinerários trilhados na construção do conhecimento na relação com as diferentes alteridades presentes em nosso cotidiano formulam uma nova constelação, cujas linhas de conexão estão a ser descobertas a cada instante (e.g. SOUZA LIMA; BARROSO, 2018). ${ }^{10}$ Tais linhas apontam a insuficiência da reprodução acrítica das dicotomias instauradas pelas epistemologias do norte na superfície do terreno colonial, nas quais índios e brancos, aldeia e cidade, artesanato, utilitário e arte, também se apresentam como caricaturas precárias para a tarefa da tradução que tenha por horizonte a afirmação das Epistemologias do Sul (SOUZA LIMA; BARROSO, 2018; SANTOS, 2019).

A socióloga e feminista boliviana Sílvia Rivera Cusicanqui (2010) questiona tais dicotomias coloniais expressas nas totalidades arbitrárias índio, branco, negro e, sobretudo, na ideia de mestiçagem calcada na ideologia da mistura, síntese artificial que habita a superfície dialética do colonialismo. Inova no campo dos estudos decoloniais ao falar do colonialismo interno como marca recorrente na experiência subjetiva americana, encarnada em sujeitos que simultaneamente se veem constrangidos pelas catergorias coloniais índiobranco-negro, e por seus artifícios caricatos mestiço, caboclo, cafuzo. A autora nos fala, alternativamente, de uma experiência manchada, dialética, sem síntese de opostos que convivem sem nunca se misturar. Nomeia Ch'ixi a condição mestiça cuja ancestralidade reconhece e evoca diferentes pertencimentos, os quais podem ou não ser acionados historicamente pelos sujeitos interessados

\footnotetext{
${ }^{10}$ Destaca-se no Brasil o esforço empreendido por Antônio Carlos de Souza Lima e pesquisadores associados ao Laboratório de Pesquisas em Etnicidade, Cultura e Desenvolvimento/LACED do Setor de Etnologia e Etnografia do Departamento de Antropologia do Museu Nacional/UFRJ que, especialmente por meio do Projeto Trilhas do Conhecimento, difundem experiências, práticas e metodologias inovadoras de interculturalidade e educação superior para indígenas no país (e.g. SOUZA LIMA; BARROSO, 2018; FREITAS, 2015).
} 
no contexto de sociedades pluriétnicas. Tais alteridades internalizadas na experiência ontológica $C h^{\prime} i x i$ se influenciam e transformam reciprocamente, aproximam e afastam sem jamais se anular ou misturar.

Tal pensamento se desenvolve no âmbito do feminismo em Abya Yala, evocado por mulheres que afirmam todas as suas ancestralidades conflitantes, avós negras, índias, brancas, todas presentes em sua identidade Ch'ixi, manchada, mestiça, mas não misturada, evocada por Sílvia Cusicanqui. Tratase de um pensar com os pés na terra, temperado na respiração e coração, ventos e águas, um pensamento-corpo-mundo insubordinado aos constrangimentos coloniais e situado na paisagem da biorregião em que habita. Esse pensamento localizado não se dobra à ideia geopolítica patriarcal de fronteira, tampouco às imposições identitárias racistas, ambas artifícios coloniais responsáveis por uma historicidade ritmada no estrondo das ruínas, das invasões e remoções violentas. Cusicanqui (2010) afirma que o paradoxo do liberalismo reside justo em, simultaneamente, apontar ideias sínteses de igualdade e evidenciar e sublinhar tais desigualdades (SANTOS; CUSICANQUI, 2013).

É no âmbito dessa ciência comprometida, dialógica, colaborativa e sensível a sistemas de conhecimento completamente álteros que se busca um percurso narrativo capaz de re-ver a mais simples categoria posta à mesa, focalizando a arte e a cidade para re-interpretá-las desde uma hermenêutica multifacetada, sem que suas múltiplas faces se misturem ou tenham nexo entre si. 


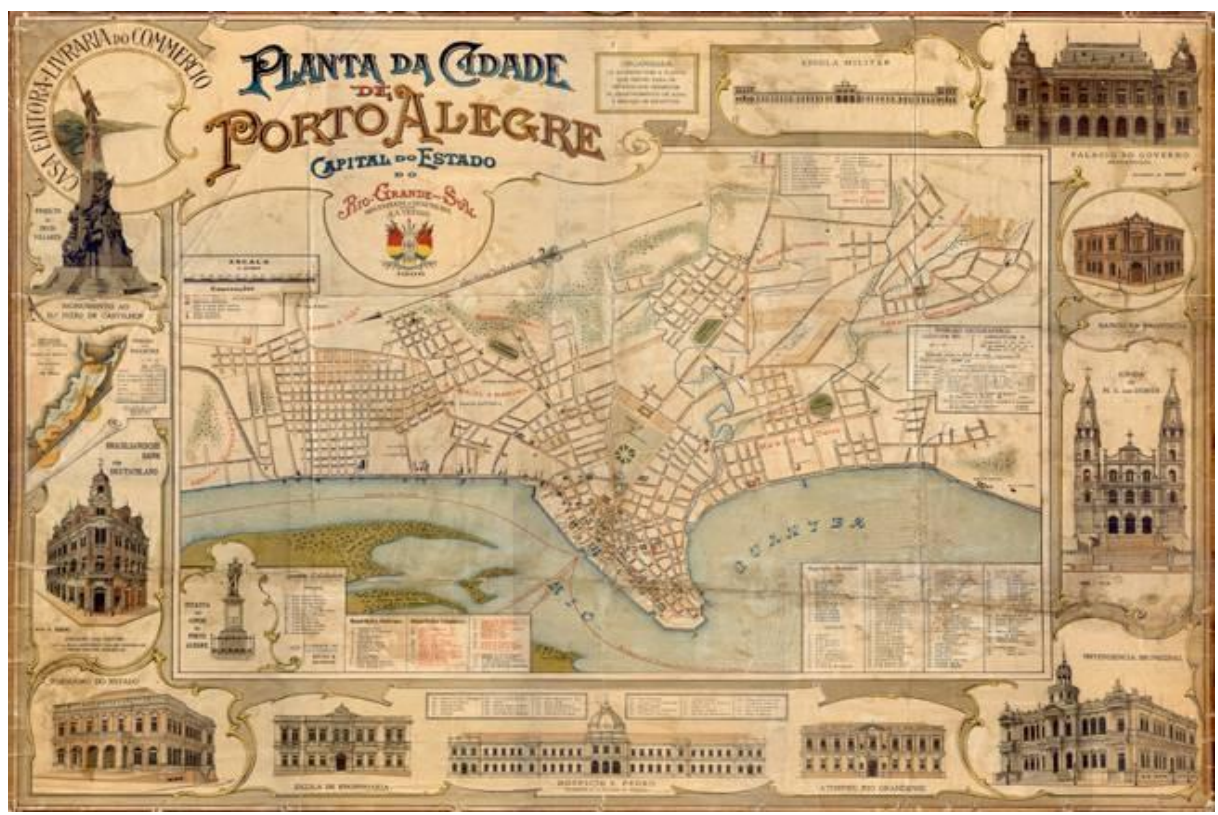

Imagem 4 - Planta da Cidade de Porto Alegre elaborada em 1906 pelo cartógrafo ítalo-brasileiro Attilio Alberto Trebbi. Daniela Fialho (2016) analisou sua moldura ilustrada com edificações da época, observando que seu "conteúdo desvela uma Porto Alegre semeada pelos ideários da política positivista enaltecendo equipamentos urbanos reveladores daquela forma de pensar a cidade e a sociedade". Acervo do IHGRGS (apud FIALHO, 2016, p. 330).

Se nas Américas as cidades constituem, em suas origens, hegemonicamente expressões coloniais geopolíticas, econômicas ou estratégicas no campo do domínio, posteriormente foram adensadas por fluxos migratórios, vértices das ondas da tempestade de progresso e desenvolvimentismo resultantes da apropriação da terra, gentes e frutos para alimentar navios mercantes que vararam oceanos transportando a seiva da Árvore da Vida na forma de riquezas intercambiáveis. Em Abya Yala a fixação de espaços geopolíticos e fronteiras não foi suficiente para estancar as dinâmicas e fluxos ameríndios, expressos em uma mobilidade constante, cujas pegadas até hoje são perceptíveis e seguem sendo trilhadas, abraçando as cidades. Uma territorialidade cujo devir é nutrido, sobretudo, pela poética da transformação permanente da materialidade da vida em suas dinâmicas de produção e reprodução, e não pela acumulação de capital e edificação, tecendo uma complexa topografia moral (TAUSSIG, 1993) ${ }^{11}$.

${ }^{11} \mathrm{O}$ conceito de topografia moral, proposto por Michael Taussig (1993, p. 285), revela a paisagem como resultante tanto da história social como da história natural. Para ele, a topografia biofísica é, 
O anjo da história lança um fugaz olhar e, com surpresa, ao ver a América colonial, recorda que nem mesmo no Velho Mundo as cidades possuíram um sentido instrumentalizado por essência, como aqui se quis conferir. E ao buscar o fôlego na reminiscência da leveza das asas, antes de serem vergadas pelas tempestades do progresso, o anjo re-encontra, entre as ruínas, a pedra fundamental de outra Cidade $^{12}$, dialeticamente Cidade Ch'ixi, mestiça pelas contradições de opostos que se complementam sem nunca se misturar, e que carreia em sua natureza mais íntima o ideal da vida em comum, presente tanto na ágora como no pátio da aldeia, isegoria que funda a pólis e, portanto, a política.
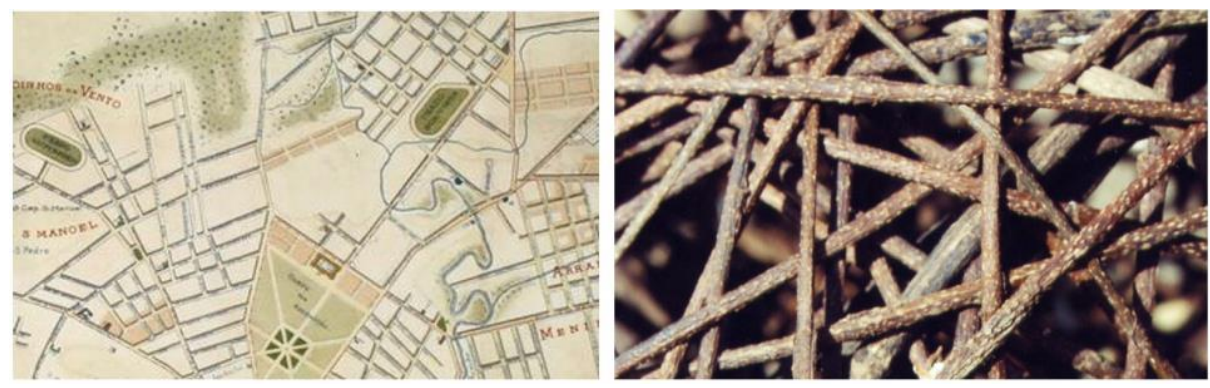

Imagens 5 e 6 - Fragmento da Planta da cidade de Porto Alegre de Attilio Trebbi (1906) ao lado de fragmento de trama de cipó confeccionada pelos Kaingang e instalado nas ruas de Porto Alegre, em 2005. Alegoria da Cidade Ch'ixi. Imagem 5. Adaptado de Fialho (2016).

Imagem 6. Freitas (2005).

Tocada pelo frescor dessa imagem, a Árvore da Vida frutifica em sementes que se espalham desde cosmovisões, que não estão contidas apenas a um tempo presente. Essas sementes encontram solos férteis na imaginação criativa que se materializa das mais diferentes maneiras: em corpos, pedras, sons, arte, palavras. A poésis reverbera uma physis em constante transformação revigorando o devir da Cidade e da Arte capaz de acolher, reconhecer e afirmar seus múltiplos pertencimentos, espaço da complexidade, uma Cidade Ch'ixi.

em certa medida, a reflexão de uma "topografia moral", produto de intervenções e interesses ora concorrentes, ora convergentes. Para Taussig, o desvelamento da topografia moral que sustenta as paisagens coloniais é um dos caminhos para compreender e transpor as bases de manutenção do próprio colonialismo.

12 Os tradutores de François Dosse (2017, p.17) observam que "No Brasil utilizamos o termo cidade no sentido de ville, espaço geopolítico. No francês, o termo Cidade (Cité) também designa o lugar do exercício da cidadania, do engajamento cívico, o sentido grego de polis, ou de 'esfera pública' no sentido de Hannah Arendt". 
Nem sempre tivemos as lentes adequadas para interpretar tudo o que atualmente (e transitoriamente) denomina-se arte indígena (DIAS, 2000; LAGROU, 2010; FREITAS, 2014; BREGALDA, 2012; 2017b; ALBINO, 2019). Sem sentido, porque anacrônicos, os conceitos de artesanato, manufatura tribal, cultura material, artefato tradicional, objetos autênticos, etc., folclorizados no corrimão perigoso das escadas do progresso e da ciência, não abrem qualquer janela ao conhecimento do que estamos a ver.

A arte indígena ingressa na contemporaneidade deslocando referências que derivam dos sistemas culturais indígenas ${ }^{13}$ para assumir uma densidade de significados e complexidade de ideias, sendo reposicionada no contexto da arte conceitual (DIAS, 2000). Uma ética atenta às alteridades perpassou diversas mentes inquietas ao longo dos séculos. Seus registros erráticos pouco encontraram eco em uma história do pensamento mais atenta em ver o Outro segundo suas formas próprias de pensar e organizar a experiência de estar vivo (INGOLD, 2015). Essa ética reencontra terreno para brotar, inspirando outros percursos narrativos.

A consciência da crise das condições de vida em escala planetária, seja no presente ou para as futuras gerações, resultou numa constante zona de inquietude. $\mathrm{O}$ anjo da história finalmente nos reaproxima, removendo outra camada de experiência na contemporaneidade. Ailton Krenak (2019), intelectual, artista e escritor krenak, em suas Idéias para adiar o fim do mundo, após conduzir o leitor às vicissitudes de nosso tempo e suas contradições quase inescapáveis, sugere benjaminianamente que a potência criativa das narrativas e a possibilidade de sua transmissão coletiva constituem uma certeza de transpor os tempos sombrios e retomar as asas para voar. Tecer um cesto a mais, um texto a mais! Uma narrativa aberta ao diálogo permanente e horizontal.

Com linhas bem traçadas, constituintes e constituidoras de significantes e significados intensamente embebidos nas águas que nutrem a Árvore da Vida, diversos intelectuais, artistas, cineastas, graffiteiros, músicos, escritores indígenas e ch'ixis vêm dialogicamente promovendo a constante revisão de certezas antes instauradas (e.g. MUNDURUKU, 2000; ESBELL, 2018, 2014; 2013, 2012; KOPENAWA; ALBERT, 2018; TABAJARA, 2018; POTIGUARA, 2018; KRENAK, 2019, 2001; CABOCO, 2019, 2019b; MAXACALI, 2019; PARÁ YXAPY, 2020).

\footnotetext{
${ }_{13}$ Para aprofundar esse debate, sugiro o estudo do texto clássico de Clifford Geertz (1997), A Arte como Sistema Cultural.
} 
As Cidades são um ponto - e não o centro - na trama da vida dessas coletividades, integrando a teia rizomática (DELEUZE; GUATTARI, 1995; INGOLD, 2012) por onde circulam seres, espíritos, corpos celestes, materiais e forças mobilizados pelos pensamentos-corpos ameríndios através de Abya Yala para abraçar toda a Terra e o Cosmos. Um pensamento que se pretenda situar no tempo-espaço em que hoje vivemos requer entrever seu traçado reconhecendo os movimentos de criação e recriação das realidades históricas, aproximando magia, técnica, arte e política - como propõe Walter Benjamin (2012) - orientando-se pela sensibilidade que emana do corpo - para então tecer itinerários outros e seguir.

Arte Indígena Contemporânea: ancestralidade na contemporaneidade

Eu aconteço, artisticamente falando, acredito, dentro de um processo que nos convida a pensar criticamente a decolonização, a apropriação cultural, o cristianismo, o monoteísmo, a monocultura e todos os dilemas do existir globalizado. Ou não? $\mathrm{O}$ meu surgimento vem junto com a expectativa que se cria em volta de outro termo, no Brasil ao menos, a arte indígena contemporânea. Não a moderna, a passada e extinta, nem a por vir, mas a deste início do século XXI. Adianto que não ando só, que não falo só, que não apareço só. Faço saber que toda a visualidade que me comporta, todas as pistas já expostas do meu existir são meramente um passo para mais mistérios. Somos por nós mesmos o poço de todos os mistérios. Faço saber ainda que não temos definição, que viemos de um tempo contínuo, sem estacionar. Antes, faço saber que buscamos os sentidos mais abstratos, tratamos de outros tratos bem firmes nessa passagem. Antes mesmo, devo dizer que tanto meu avô Makunaima quanto eu mesmo, parte direta dele, somos artistas da transformação. Surgimos junto com a arte e todos os desafios do grande existir e suas mais claras urgências individuais e coletivas. Surgimos no aparente caos, como é mesmo descrito entre os grandes Xamãs do mundo e um quase consenso na ciência, em termos de rumos para a humanidade tal qual. O prenúncio matemático do fim do mundo é também um cenário de nossa aparição. Como produto, também desse tempo, tenho a ideia de que a colonização foi um processo, embora saiba que trata-se de um ato contínuo. Assim, olhei para todos os lados e vi meu o avô no horizonte. No horizonte está claro também que não haverá cultura tampouco vida e vida de qualidade, muito menos - para quem quer que seja em nada sendo feito. Não é possível, caso não rompamos alguma membrana extra do agora, pensar uma ideia de futuro em questões de nossa ligação espiritual com a terra e com o nosso lixo. Adianto, Makunaima não é só um guerreiro forte, másculo, macho e viril distante de uma realidade 
possível, não senhores. Ele é uma energia densa, forte, com fonte própria como uma bananeira (ESBELL, 2018. p.11-12) ${ }^{14}$

De que arte falamos quando nos dispomos a pensar itinerários de arte indígena nas cidades contemporâneas? Arte Vida, plena de pulsão vital, em que os fluxos de uma gama extraordinária de materiais são avivados pelas forças ameríndias, num Cosmos em permanente transformação (INGOLD, 2015). Arte pública, arte mundo (OLIVEIRA, 2012), coletiva incontinente movimento que, numa constelação, integra cestos e tramas de fibras vegetais, que vicejam nas florestas, e a arte urbana, ocupando as ruas, os muros e o asfalto, perpassando galerias e museus, instalando telas, tintas, panos, performando pajelança, onça, pajé, publicando livros e exibindo filmes que desacomodam as perspectivas vigentes, produzindo discos, graffitis, podcasts e outras paragens, sem espaço de contradição. Arte contestação a reverberar as vozes indígenas diante das tempestades do progresso.

14 Entre outros escritos, Makunaima, meu avô em mim! (ESBELL, 2018) é um ensaio iconopoético autoral em que o artista, escritor, curador e produtor cultural Jaider Esbell mobiliza imagens seminais para a qualificação do debate acerca da arte indígena contemporânea. Pleno de potências ancestrais, Jaider passeia pelas imagens fabulosas do universo onírico de Makunaíma, seu avô; artista da transformação, suas urgências individuais e coletivas integram o cenário de sua aparição, em meio ao caos da dissolução do tempo. 


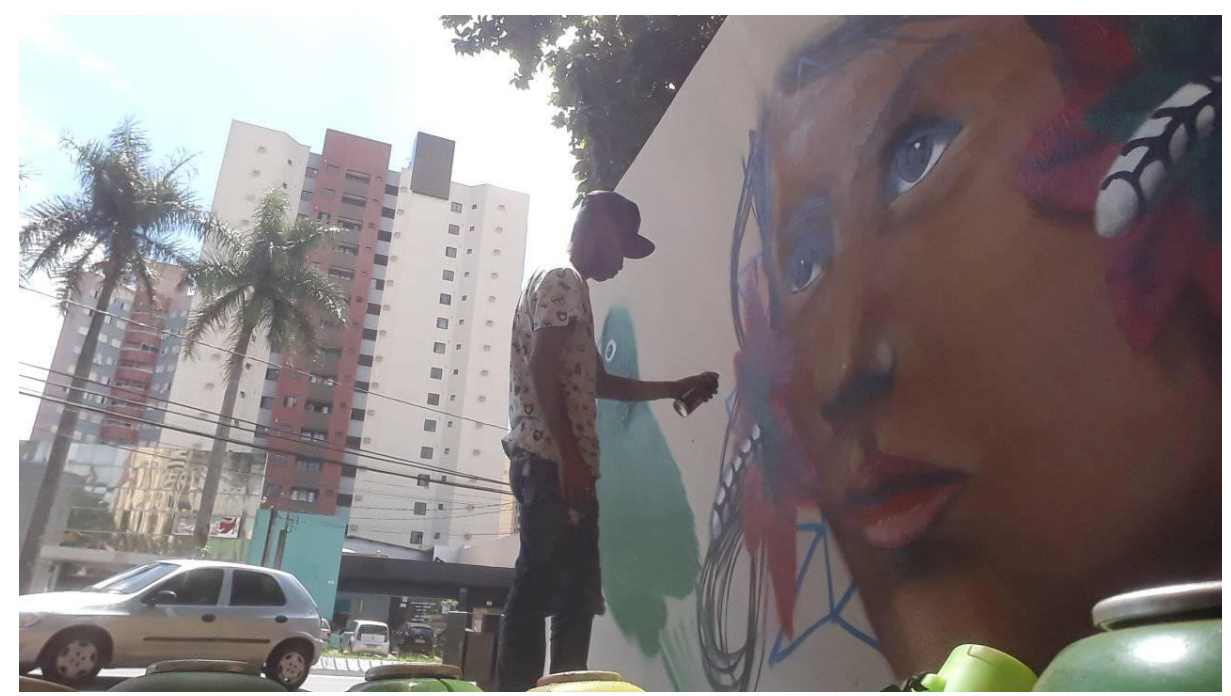

Imagem 7 - Soverino Mygso Borges, artista Kaingang, produzindo graffiti nos muros do Colégio Estadual Vicente Rijo. Soverino integra o Grupo Nēn Ga, ao lado de jovens artistas que residem na Terra Indígena Apucaraninha, e participa do movimento de Arte Urbana na cidade de Londrina, Paraná. Fotografia do artista. Facebook, página de Soverino Mygso Borges, (17 de janeiro de 2020).

Ao propor o deslocamento metodológico na direção da noção de Arte Vida para pensar a arte indígena nas cidades, busco transpor a abordagem que elege as rotas classificatórias assumidas pela arte nos sistemas culturais, para aproximar o olhar dos fluxos, relações e materiais que envolvem as coletividades indígenas no urbano, numa perspectiva da antropologia ecológica (INGOLD, 2012;2015).

O movimento de arte indígena contemporânea, autorreferido pelos povos indígenas, emerge na segunda década do século XXI. Um conjunto de intelectuais indígenas participa de sua formulação, destacando-se as reflexões de Jaider Esbell (e.g. 2016, 2018).

A partir da primeira década do século XXI, um conjunto de políticas de ação afirmativa instaura vagas de cotas que recepcionam jovens indígenas em diversas universidades públicas brasileiras. Pertencentes a diferentes povos e regiões do país, esses jovens intelectuais indígenas compreendem as universidades como zonas de influência de seus povos e territorialidades (SAMPAIO, 2017). Sua presença promove uma série crescente de rupturas institucionais, afetando rotinas administrativas, práticas pedagógicas, projetos e programas. 
Novas teias de relações sociais se estabelecem no interior das universidades, a partir das posições que passam a ser ocupadas pelos estudantes indígenas em laboratórios, grupos de pesquisa, eventos e projetos de extensão, nas diversas áreas de conhecimento. Trata-se de um evento importante na cena contemporânea da vida indígena brasileira, um ponto de inflexão potencialmente positivo nas relações das cidades com os povos indígenas. Passadas duas décadas, uma geração de intelectuais indígenas artistas, cientistas sociais, educadores, escritores, incide significativamente na cena cultural brasileira. Ingressam em circuitos de arte urbana e estabelecem circuitos próprios, através de alianças interculturais envolvendo diferentes instituições.

O conceito de montagem recepcionado na ideia de instalação artística passa a ser incorporado em obras de arte indígena contemporânea, sendo exemplar a obra Cobra Grande, instalação de proporções monumentais de autoria de Jaider Esbell, que integrou o CURA - Circuito Urbano de Arte 2020, na cidade de Belo Horizonte.

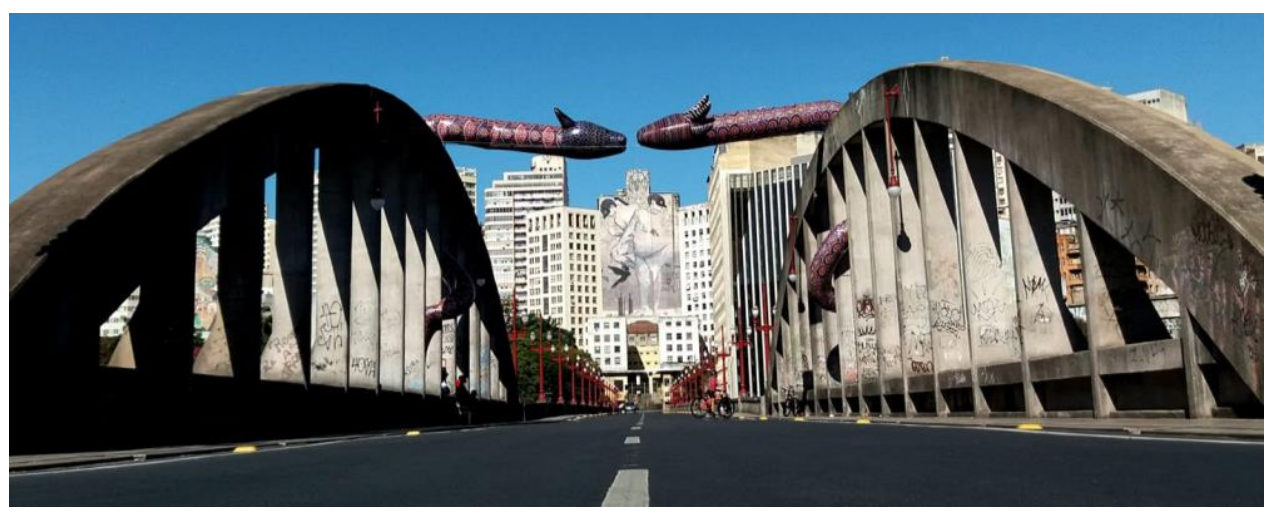

Imagem 8 - Obra de Instalação Cobra Grande, Belo Horizonte, setembro de 2020, durante o CURA - Circuito Urbano de Arte de Belo Horizonte. Facebook, página de Jaider Esbell (14 de outubro de 2020).

Inspirada no movimento de vanguarda da arte indígena contemporânea, proponho pensar a arte indígena exposta e comercializada nas ruas e praças das cidades expandindo a perspectiva conceitual e analítica da instalação artística, em contraposição à redução colonial implícita na ideia de artesanato, que condiciona o olhar e reduz a potência conceitual das esculturas tridimensionais de fibras vegetais expostas nas cidades pelos povos indígenas 
Os fluxos de materiais e forças (BACHELARD, 1991; INGOLD; 2012) mobilizados nos itinerários de arte indígena nas cidades expandem os sentidos e significados que assumem nos sistemas culturais indígenas quando ingressam no sistema cultural da arte contemporânea ${ }^{15}$, evocando uma trama rizomática (DELEUZE; GUATTARI, 1995), aludindo à incidência da vida diante das tendências de redução, territorialização e gentrificação (ARANTES, 2013), evocação poética que reivindica o direito indígena à cidade, ao território, à vida, e amplia o horizonte de possibilidades para o urbano na contemporaneidade.

Pelo fluxo da arte, coletividades e artistas indígenas se movimentam no território - e nos movimentamos com eles! - desfazendo fronteiras e re-tecendo redes no grande mosaico das paisagens, nas cidades, reais-virtuais, recriadas no andar. Navegamos milhares de quilômetros, reafirmando solidariedades, retecendo cestos e circulando a seiva da Árvore da Vida, que se refaz em sementes, filhos e netos - para enfim, e novamente, parir nossos avós em nós (ESBELL, 2018; CABOCO, 2019).

${ }^{15}$ Ver Clifford Geertz, A arte como sistema cultural (1987). 


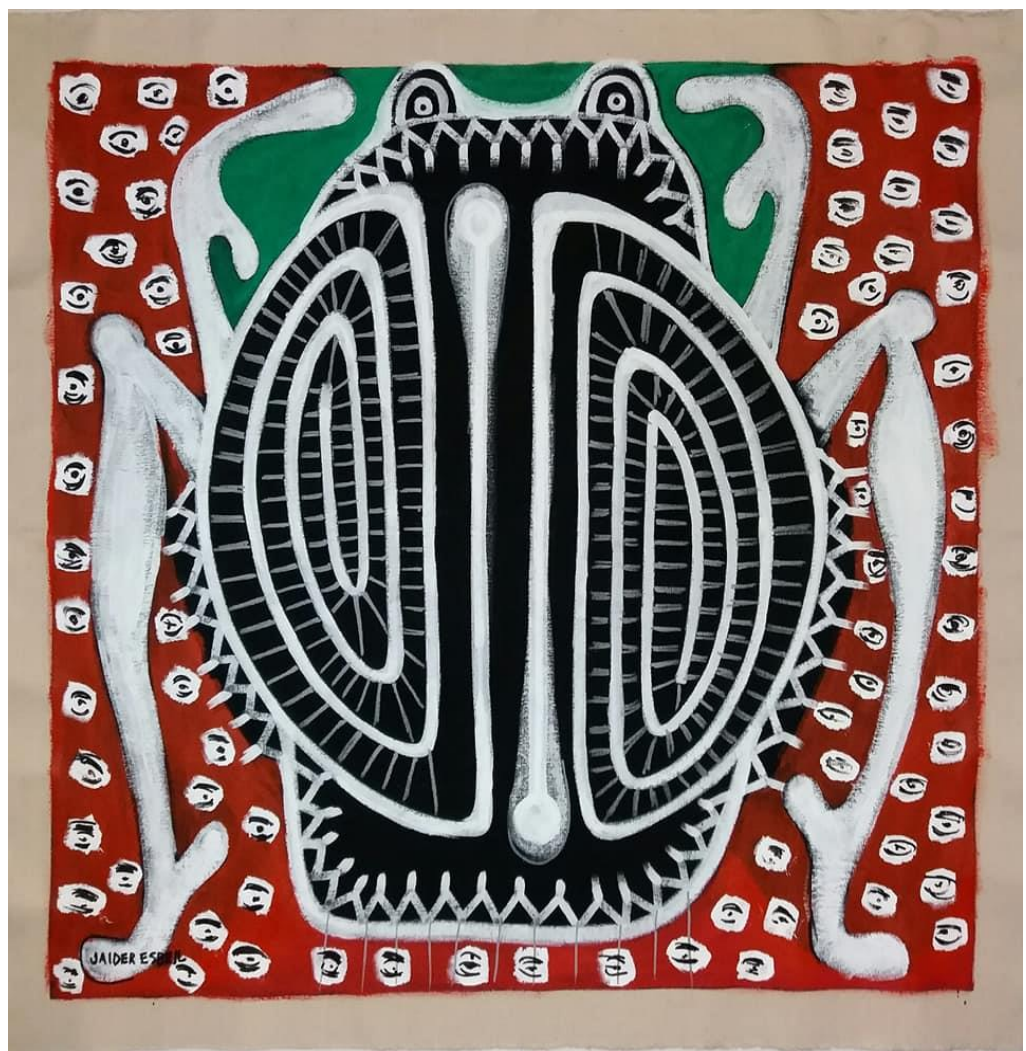

Imagem 9 - O Parto de Makunaima. Jaider Esbell. 2018.90 x $90 \mathrm{~cm}$. Acrílica e marcador à base

d'água. Uma das 12 telas da série Transmakunaima - o buraco é mais embaixo, narrando as

andanças de Makunaima, afetuosamente um avô, cheio de netos, sendo o próprio artista um deles, que brotam de Wazak'á, Árvore da Vida, se espalhando da Raposa Serra do Sol pela cidade de Boa Vista e além, dilatando os horizontes do enorme espaço Panamazônico circumroraimense (Coleção particular da autora).

Para além da superfície das formas econômicas, a arte é o caminho que a eco-lógica ameríndia elege e persegue para manter ativa nossa conexão na teia da vida (FREITAS, 2005). Seus filamentos se expandem para além das ruínas coloniais, escapando para o céu, rompendo o quadro numa profusão de linhas orgânicas - como vislumbrou Lygia Clark (1980) - , em ramos, raízes e galhos, e mantendo a floresta em pé! em meio às tempestades do progresso. 


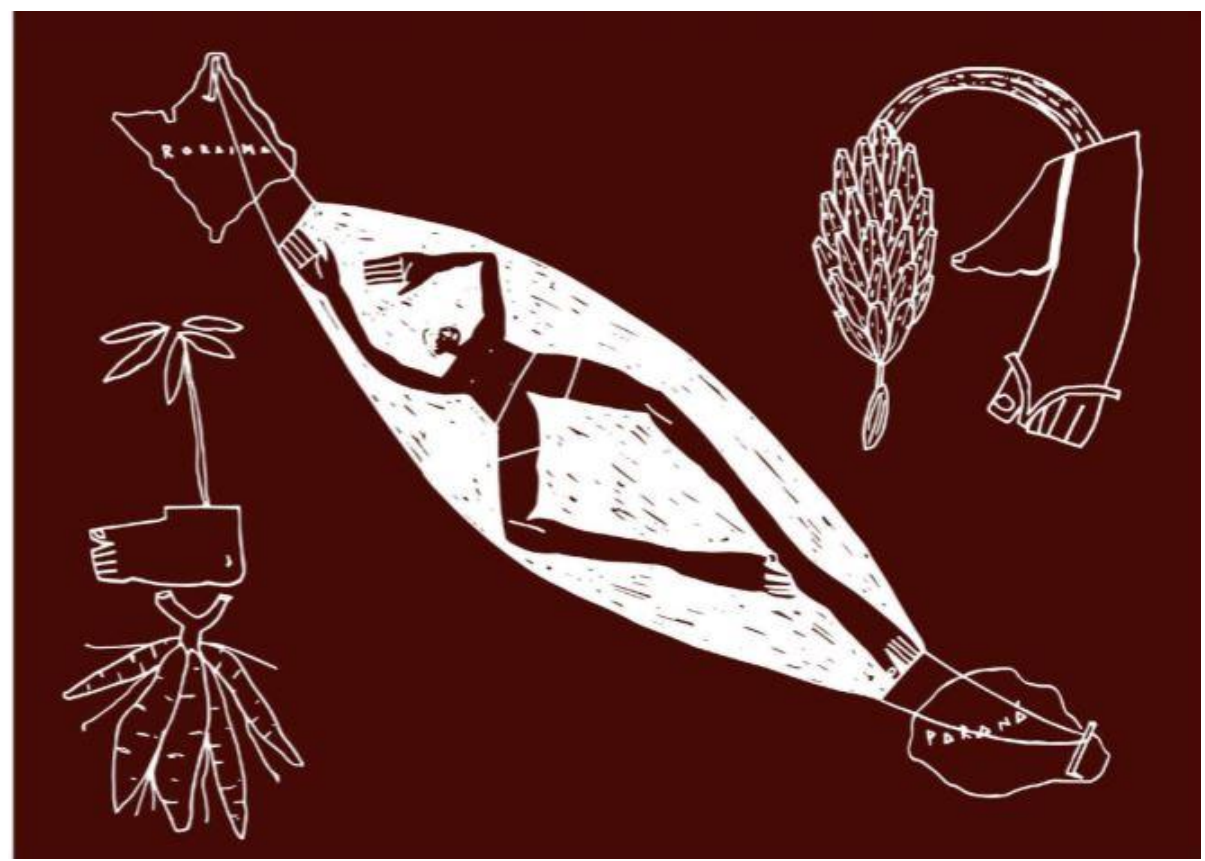

Imagem 10 - Rede-Mãe. Obra que integra o ensaio iconopoético "Sou uma extensão Wapichana, povo indígena de Roraima" (CABOCO, 2019b, p.65). Gustavo Caboco, fruto de Wazak'á, neto de Makunaimî, é artista indígena contemporâneo nascido em Curitiba, cuja obra estende uma rede tecida pelas memórias de sua mãe Lucilene, unindo a cidade de Curitiba a Canauanim, Roraima, e abraçando o mundo.

É preciso afirmar que a arte que sustenta o viver ameríndio nas cidades por onde passa integra um modo de vida cuja ontologia se replica sem nunca ser igual, em extraordinária diversidade e nos mais variados contextos urbanos. Através de Abya Yala, por meio da arte, os coletivos indígenas reafirmam vínculos societários, costurando ruas, campos e florestas, deslocando e transformando matérias da terra, rememorando expedições de caça aos porcosdo-mato (krág), peixes (pirã), pinhão (fág fy), bananas, jenipapo e outras frutas que vicejam nessa Terra (FREITAS, 2005).

Seguindo a perspectiva de Paulo Renato Damé (2007), as instalações de arte indígena nas cidades funcionam como dispositivos relacionais, oportunizando outras relações sociais e desfazendo arestas que nos separam Uns dos Outros. No fio da história, da mesma maneira, os objetos instalados e desinstalados no tecido urbano, em constelações nunca iguais, funcionam como dispositivos de desaceleração do tempo na cidade, convidando para uma pausa nos itinerários 
convencionais ${ }^{16}$. Uma rede de intelectuais, artistas, cineastas, escritores, performers, produtores culturais pertencentes a diversos povos indígenas se estende pelo espaço cibernético, produzindo projetos colaborativos, curadorias compartilhadas e intervenções em museus, galerias, bienais, universidades, ruas das cidades, em escala nacional e global.

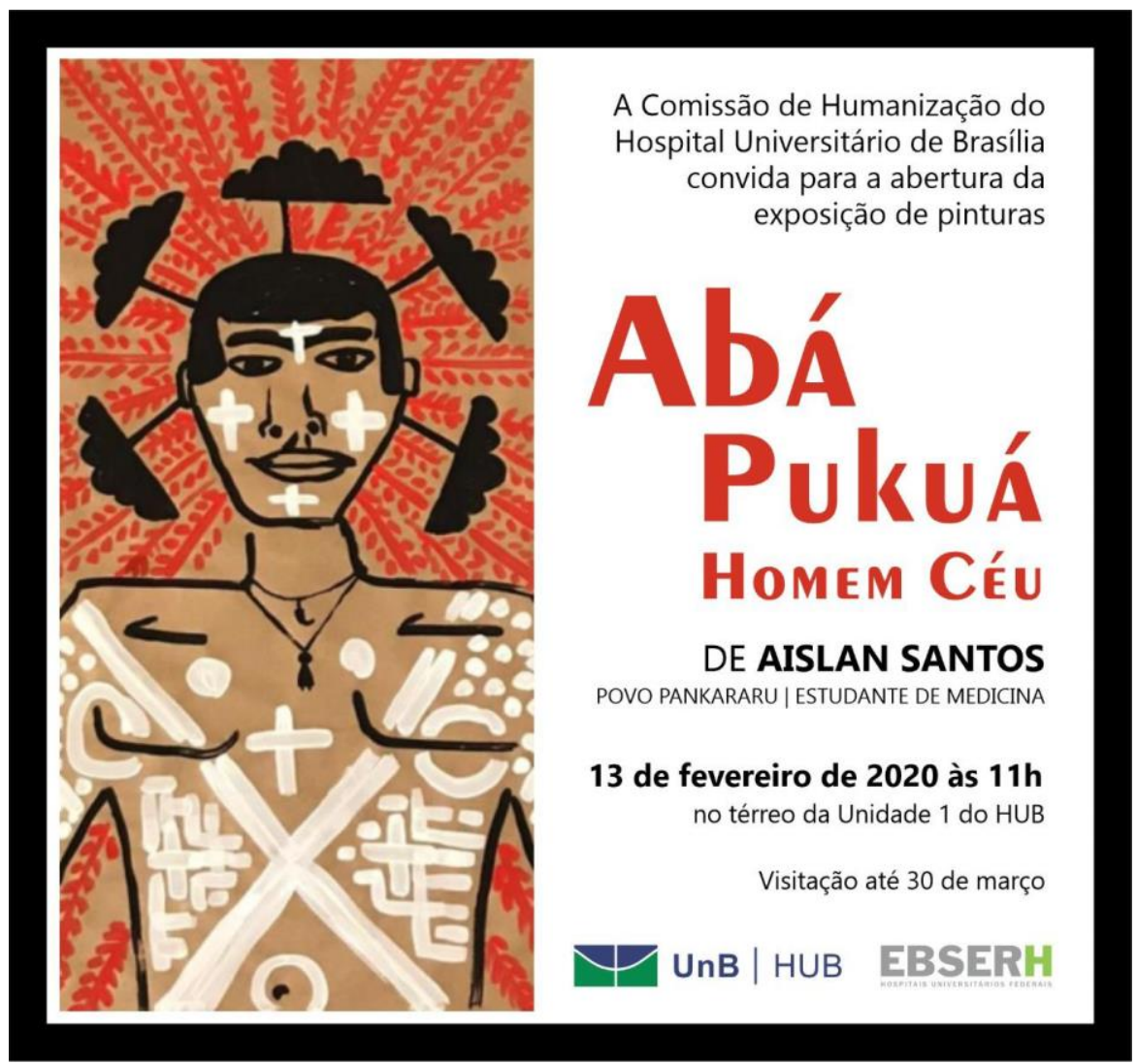

Imagem 11 - Cartaz da exposição Abá Pukuá, do artista pankararu Aislan Santos, organizada pela Comissão de Humanização do Hospital Universitário de Brasilia, 2019.

Damiana Bregalda (2017) focaliza a atuação de alguns desses artistas nas Bienais de São Paulo. Obras de Ailton Krenak, Naine Terena, Davi Kopenawa,

\footnotetext{
${ }^{16}$ Paulo Renato Damé (2007) em seus estudos de arte relacional, inseriu a pedra 0,42 em diferentes espaços urbanos em sua pesquisa em arte relacional junto a José Luiz Kinceler, na Universidade Estadual de Santa Catarina, propondo que tais objetos, assim inseridos em percursos cotidianos, potencialmente reposicionam as pessoas em seus trânsitos, operando como táticas artísticas de desaceleração.
} 
Denilson Baniwa, Aníbal Lopes, entre outros, integram sua pesquisa (BREGALDA, 2017; 2017b). Do mesmo modo, outros pesquisadores colaboram na difusão dessa potente produção artística, em teses, dissertações, ensaios e artigos (e.g. LAGROU, 2010; PINHEIRO, 2017; LISBOA, 2018; COSTA, 2019; ALBINO, 2019).

O reconhecimento da contemporaneidade dos conhecimentos sintetizados nas obras de arte indígena amplia não apenas os horizontes dos índios nas cidades, mas também da Arte e da própria Cidade, fertilizada com as seivas da floresta e da humanidade, reconciliada com sua ancestralidade.

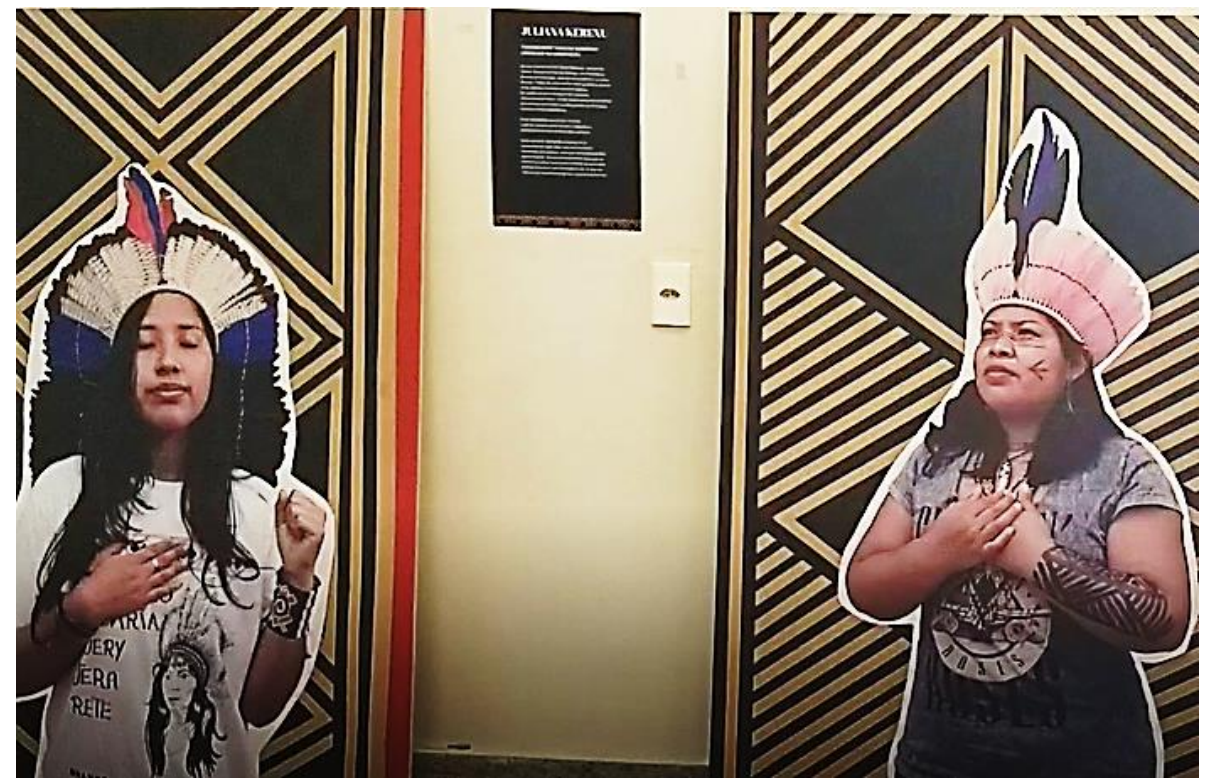

Imagem 12 - Obras da série Xondarias, da artista Mbyá Guarani Juliana Kerexu, em exposição no Setor Litoral da Universidade Federal do Paraná, 2019. A obra de Juliana evoca poderes femininos que, com sua força ancestral e luta, promovem a vida Guarani (Foto da autora).

Rememoro a imagem fornecida por meus interlocutores Zílio Jagtyg Salvador e Francisco Rokàg dos Santos, quando, em nossas andanças em Porto Alegre, comparavam um emaranhado de cipó (gòje) na floresta com a família kaingang, em que o tronco principal é pai e os ramos filhos. Dialeticamente, a Árvore da Vida na eco-lógica Kaingang se reencontra no espelho da Cidade, espaço de reinvenção da vida social na tecitura de um cesto, tramado com os fios de uma epistemologia que refaz o percurso traçado pelas fibras de cipó das florestas ao urbano. 
À luz da expansão dos percursos da arte indígena contemporânea, é possível reposicionar o desafio perspectivo proposto pelos Kaingang, ao deslocar fibras vegetais das florestas de Porto Alegre, humanizadas, familiarizadas e culturalizadas numa infinidade de formas tridimensionais, instaladas e desinstaladas nas ruas da cidade. Tal reposicionamento dilui as fronteiras que separam tradição e contemporaneidade, para reconhecer no conjunto dessas obras uma extraordinária potência conceitual. A arte indígena contemporânea instalada no urbano instaura uma experiência que desfoca a cidade de sua dimensão de espaço construído, ordenado, antrópico, e a restitui de sua dimensão cosmo-mundo - espaço de saber, fazer e viver.

Nas cidades de Porto Alegre, Curitiba, Brasília, Londrina, Boa Vista, Belo Horizonte, nas Bienais de São Paulo, em toda a parte, itinerários de arte indígena contemporânea atravessam dadivosamente o concreto, seus ângulos e retas, renovando os ares e colorindo o cinza com linhas orgânicas que se instalam e desinstalam cotidianamente, escapando aos quadros-muros e convidando a estar na rua. Transformam espaços ordinários em espaços extraordinários, alterando o ritmo urbano.

Mobilizadas por essa perspectiva, fotografias e obras de cipó trançado, recolhidas nas passagens de Porto Alegre, entre 1996 e 2009, acompanhando interlocutores Kaingang em seus percursos de deslocamento e transformação das fibras de cipó lascado das florestas para as ruas da cidade, entram em constelação com telas, filmes, livros e bananeiras. Integram projetos de curadoria compartilhada com artistas indígenas, participantes e colaboradores, resultando em instalações, plenas de movimento. Imagens dialéticas, atravessam esboços curatoriais de arte indígena contemporânea na cidade de Curitiba, desenhados colaborativamente, ampliando o espaço cibernético através dos corredores e escadarias que circundam o Museu de Arte da Universidade Federal do Paraná. 


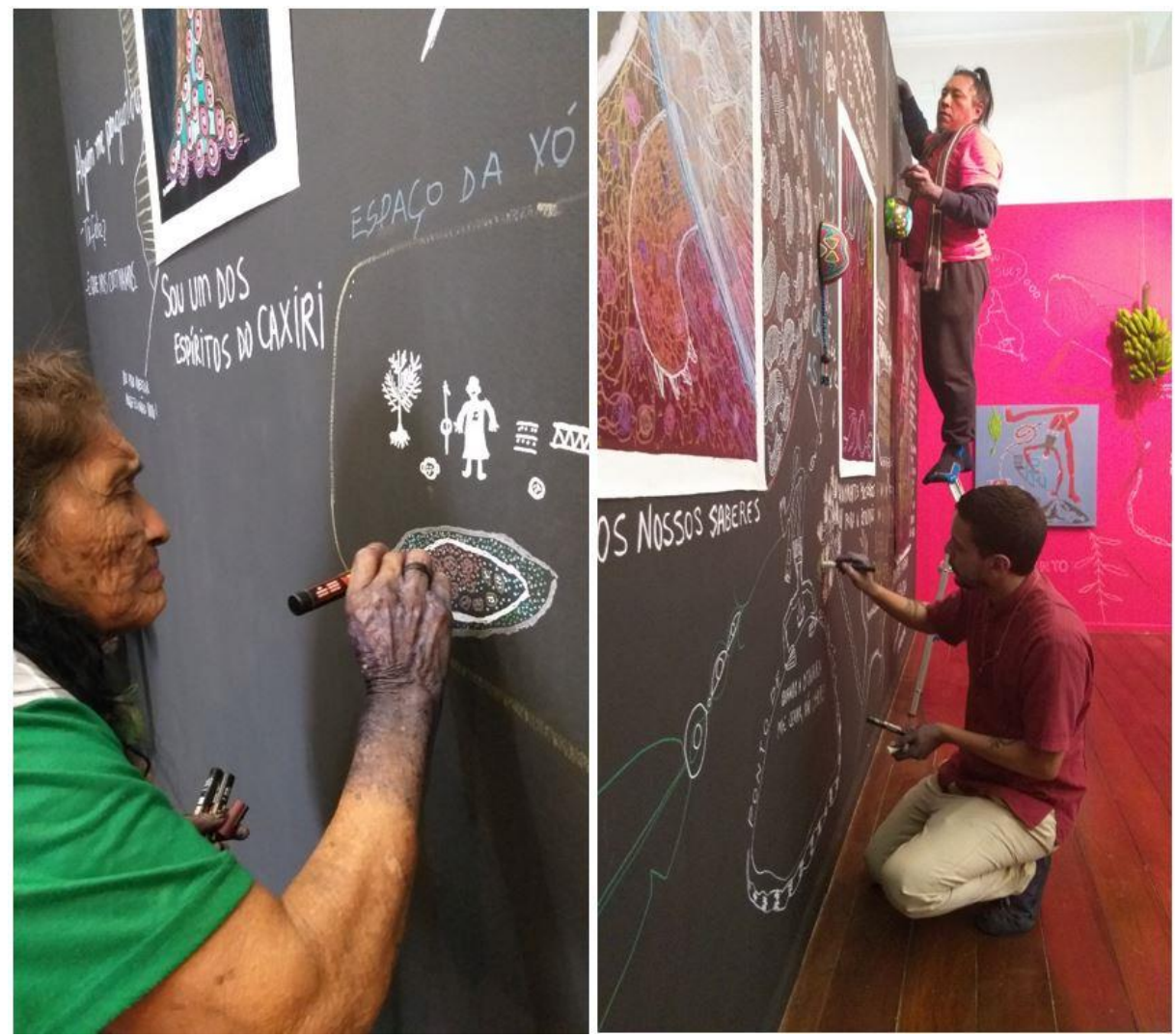

Imagens 13 e 14 - Montagem colaborativa da instalação “Netos de Makunaimî: encontros de arte indígena contemporânea" no Museu de Arte da Universidade Federal do Paraná, cidade de Curitiba, 2019. À esquerda, Vó Bernal - Bernaldina José Pedro Meriná (in memorian); à direita, Gustavo Caboco e Jaider Esbell (Fotos da autora).

Por meio da arte indígena, a cidade dilata seus horizontes de possibilidades ao recepcionar seus itinerários. Dialeticamente, ao se engajar nos itinerários de arte indígena nas cidades, pessoas e coletividades desacomodam o imaginário colonial restituindo a condição contemporânea da cidadania, pensamento e ação. A cidade, reencantada pelos fluxos de materiais e forças mobilizados na arte indígena contemporânea, torna-se ela mesma quadro e obra em permanente recriação, ampliando seu horizonte de possibilidades, reinventando a ágora, revigorando a pólis nos sentidos de uma Cidade Ch'ixi, Cidade Aqui, diante da possibilidade de ver, ouvir, acolher, conviver, conhecer todos os nossos coletivos, ecologias e pensamentos.

E o parto não para por aqui. 

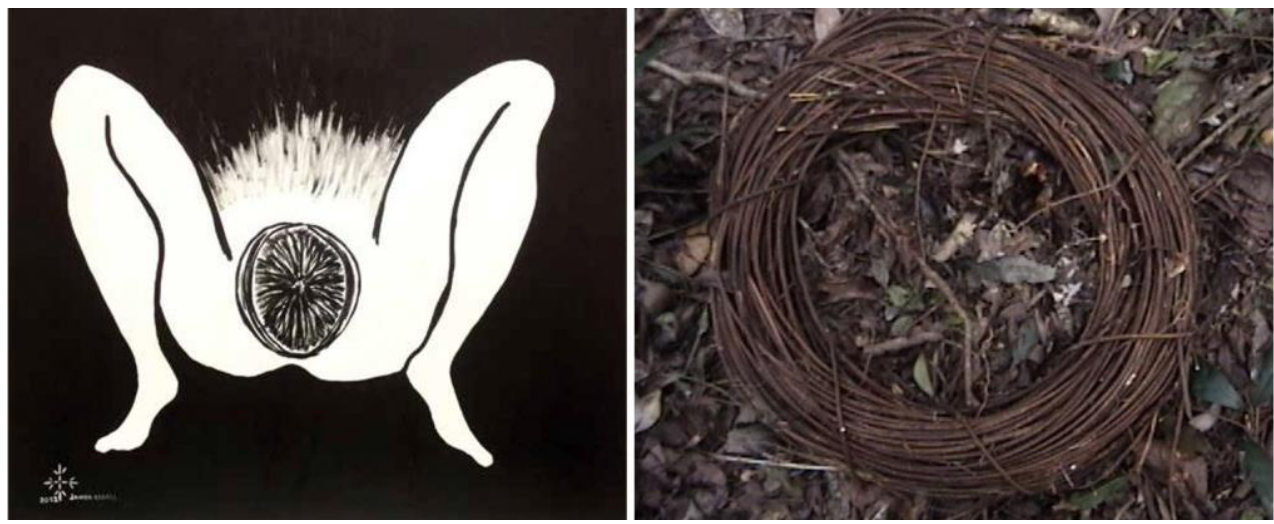

Imagens 15 e 16 - Mais um parto. Jaider Esbell. Coleção Cabocagem. Acrílica sobre tela. 93 x 83 cm (ALMEIDA; MATOS 2013, p. 199). Rolo de cipó marronzinho no chão de floresta no Morro do Osso, cidade de Porto Alegre (Foto da autora).

\section{Referências}

ALBIN0, Paula Berbert Ferreira.

(2019). Tecendo redes de alianças afetivas: algumas notas sobre arte indígena contemporânea e práticas curatoriais. Monografia de Especialização em Estudos e Práticas Curatoriais apresentada à Fundação Armando Álvares Penteado.

ARANTES, 0tília; VAINER, Carlos; MARICATO, Ermínia (Org.).

(2013). A cidade do pensamento único: desmanchando consensos. 8. ed. Petrópolis, RJ: Vozes.

BACHELARD, Gaston.

(1991). A Terra e os Devaneios da Vontade: ensaio sobre imaginação das forças. São Paulo: Martins Fontes.

\section{BAINES, Stephen.}

(2001). As chamadas "aldeias urbanas"ou índios nas cidades. Revista Brasil Indígena, ano 1, n.7.

BENJAMIN, Walter.

(2012). Magia e Técnica, Arte e Política: ensaios sobre literatura e história da cultura. Obras escolhidas. 8. ed., vol.1. São Paulo: Brasiliense.
(2011). A tarefa do tradutor. In: BENJAMIN, Walter. Escritos sobre mito e linguagem. Coleção Espírito Crítico. São Paulo: Ed. Duas Cidades, Ed. 34. p. 101-119.

(2009). Passagens. Belo Horizonte, Ed. UFMG. São Paulo, Imprensa Oficial do Estado de São Paulo.

BOSCO E SILVA, Luciana.

(2009). Cidade/arte: a instalação e sua transmutação em objeto expandido no meio urbano. LAV Revista Digital do Laboratório de Artes Visuais (UFSM), n.2. p. 1-17.

\section{BRASIL.}

(1967). Relatório Figueiredo. Jader de Figueiredo Correia. Ministério do Interior.

BREGALDA [JAENISCH], Damiana.

(2012). A arte Kaingang da produção de objetos, corpos e pessoas: Imagens de relações nos territórios das Bacias do Lago Guaíba e Rio dos Sinos. Dissertação de Mestrado apresentada ao Programa de Pós-Graduação em Antropologia Social da Universidade Federal do Rio Grande do Sul. 
(2017a). Poéticas e políticas da relação: apontamentos a partir da ação de Ailton Krenak na Assembléia Nacional Constituinte e seu deslocamento para espaços de arte contemporânea. Iluminuras. v. 18, n. 43, Porto Alegre. p. 215-239.

(2017b). Cosmocoreografias: poéticas e políticas do mover - entre artes e territórios indígenas e da arte contemporânea. Tese de Doutorado em Arte pela Universidade Federal do Rio de Janeiro.

CABOC0, Gustavo.

(2019a). Sou uma extensão Wapichana, povo indígena de Roraima. TOM Caderno de Ensaios, vol.5, n.10, Curitiba, p. 62-71.

(2019b). Baaraz Kawau - o campo após o fogo. Curitiba: Impressões Indígenas.

CARDOSO DE OLIVEIRA, Roberto.

(2006). Caminhos da identidade - ensaios sobre etnicidade e multiculturalismo. São Paulo: Ed. Unesp; Brasília: Paralelo 15.

CARDOSO DE OLIVEIRA, Roberto; CARDOSO DE OLIVEIRA, Luis Roberto.

(1996). Ensaios antropológicos sobre moral e ética. Rio de Janeiro: Tempo Brasileiro.

CARNEIRO DA CUNHA, Manuela; BARBOSA, Samuel (org.)

(2018). Direitos dos Povos Indígenas em disputa. São Paulo: Ed. Unesp.

CLARK, Lygia.

(1980). Textos de Lygia Clark, Ferreira Gullar e Mário Pedrosa. Rio de Janeiro: Funarte.

COSTA, Vanessa Augusta do Nascimento Brandão e.

(2019). O neto de Makunaima: Jaider Esbell e a literatura indígena em Roraima. Dissertação de Mestrado apresentada ao Programa de PósGraduação em Letras da Universidade Federal de Roraima.

CUSICANQUI, Silvia Rivera.

(2010). Ch'ixinakax utxiwa: una reflexión sobre prácticas y discursos descolonizadores. Buenos Aires, Tinta Limón.
DAMÉ, Paulo Renato Viegas.

(2007). Inserindo dispositivos relacionais: táticas artísticas para desacelerar. Dissertação de Mestrado apresentada ao Programa de PósGraduação em Artes Visuais da Universidade do Estado de Santa Catarina.

DELEUZE, Gilles; GUATTARI, Félix.

(1995). Mil platôs: capitalismo e esquizofrenia. vol.1. Rio de Janeiro: Ed. 34.

DIAS, José António Braga Fernandes.

(2000). Arte, arte índia, artes indígenas. In AGUILAR, Nelson (org.). Mostra do Redescobrimento: artes indígenas. São Paulo, Associação Brasil 500 Anos Artes Visuais.

LAGROU, Els.

(2010). Arte ou artefato? Agência e significado nas artes indígenas. Revista Proa, vol. 1, n. 2.

ESBELL, Jaider.

(2018). Makunaima, o meu avô em mim! Iluminuras, v. 19, n. 46, p. 11-39, jan/jul. Porto Alegre. Disponivel em: $<$ https://seer.ufrgs.br/iluminuras/article/vie w/85241/49065>. Acesso em: 25 jan. 2020.

(2014). Eu sonho em ter um grande caminhão para colocar todo mundo dentro e passar um mês numa aldeia, um mês na outra, para construir essa cultura coletiva. Mundo Amazónico. n. 5. p. 253-259.

(2013). Tardes de agosto manhãs de setembro e noites de outubro. Boa Vista, Edição do Autor.

(2012). Terreiro de Makunaima: Mitos, lendas e estórias em vivências. Belém, Cronos.

FAJARD0, Raquel Yrigoyen.

(2011). El horizonte del constitucionalismo pluralista: del multiculturalismo a la descolonización. In:

GARAVITO, César Rodríguez (Coord.). El Derecho en América Latina: un mapa para el pensamiento jurídico del siglo XXI. Buenos Aires: Siglo Veintiuno. p.139-160. 
FIALH0, Daniela Marzola.

(2016). A Planta de Porto Alegre (RS) de 1906. In: Anais do 30 Simpósio Brasileiro de Cartografia Histórica, Belo Horizonte, p. 329-338.

FREITAS, Ana Elisa de Castro.

(2020). Netos de Makunaimî: encontros de arte indígena contemporânea. Texto Curatorial de Instalação Artística. Museu de Arte da Universidade Federal do Paraná. Período expositivo: de 28 de novembro de 2019 a 30 de abril de 2020.

(2018). Apresentação. Dossiê Imagem e Descolonização - Imaginários plurais em movimento. Iluminuras., v.19, n. 46. Porto Alegre. p. 05-10, jan/jul.

(2016a). A poética do belo caminhar: Arte, ecologia, resistência e narrativa Mbyá Guarani. TOM Caderno de Ensaios, vol.2, n.4. Curitiba. p. 36-47.

(2016b). Identidades indígenas e seu reconhecimento: leituras de antropologia e direito. In: MENDES, Aluísio Gonçalves de Castro; SILVA, Fernanda Duarte Lopes Lucas da; CRUZ, Adriana Alves dos Santos; CUNHA, Michele Menezes da. (org.) A Questão Indígena e o Poder Judiciário - programa de estudos avançados. Tribunal Regional Federal (2a . Região). Escola da Magistratura Regional Federal da $2^{a}$. Região. Rio de Janeiro: EMARF. p. 39-55.

(2014). Garra de jaguar, botão de camisa, cartucho de bala: um olhar sobre arte, poder, prestígio e xamanismo na cultura material Kaingang. Revista Mediações. Londrina, v. 19 n. 2. p. 62-83.

(2008). Nossos contemporâneos indígenas. In: FREITAS, Ana Elisa de Castro; FAGUNDES, Luis Fernando Caldas (Orgs). Povos Indígenas na Bacia Hidrográfica do Lago Guaíba, Porto Alegre, Rio Grande do Sul, Brasil. Porto Alegre: Editoras Associadas. p. 5-13.

(2005). Mrũr Jykre: A cultura do cipó Territorialidades Kaingang na margem leste do Lago Guaíba, Porto Alegre, Rio Grande do Sul, Brasil. Tese de Doutorado apresentada ao Programa de Pós-Graduação em Antropologia
Social da Universidade Federal do Rio Grande do Sul.

FREITAS, Ana Elisa de Castro; BUEN0, Antonio Augusto; FIDELIS, Jaciele Nyg Kuita.

(2018). Traço - pulso primordial. Imagens em movimento entre cavernas e galerias. Iluminuras. v.19, n. 46. Porto Alegre. p. 436450.

FREITAS, Ana Elisa de Castro; FAGUNDES, Luis Fernando Caldas (Orgs).

(2008). Povos Indígenas na Bacia Hidrográfica do Lago Guaiba, Porto Alegre, Rio Grande do Sul, Brasil. Porto Alegre: Editoras Associadas.

FREITAS, Ana Elisa de Castro; HARDER, Eduardo. (2018). Os povos indígenas no ensino superior e os caminhos para a efetivação da justiça e do Bem Viver. In: COSTA E FONSECA, Ana Carolina da; LEIVAS, Paulo Gogo (Orgs.), 2018. Direitos humanos e saúde. Vol. 1. Porto Alegre: Ed. da UFCSPA. Recurso on-line (319 p.). Disponível em:

http://www.ufcspa.edu.br/index.php/editora / obras-publicadas

GEERTZ, Clifford.

(1997). A arte como sistema cultural. In: GEERTZ, Clifford. O Saber Local. 4. ed. Petrópolis: Editora Vozes.

GROS, FRÉDÉRIC

(2011). Caminhar, uma filosofia. São Paulo: É Realizações.

INGOLD, Tim.

(2020). Estar vivo - ensaios sobre movimento, conhecimento e descrição. Coleção Antropologia. Petrópolis: Editora Vozes.

(2012). Trazendo as coisas de volta à vida: emaranhados criativos num mundo de materiais. Horizontes Antropológicos. Ano 18, n. 37. p. 25-44.

KLEE, Paul.

(1920). Angelus Novus. Desenho em nanquim e pastel aquarelado sobre papel. $31,8 \times 24,2 \mathrm{~cm}$. Museu de Israel, Jerusalém. Disponível em: http://www.acervofilosofico.com/o-anjo-debenjamin/. Acesso em: 30 jan. 2020. 
KOPENAWA, Davi; ALBERT, Bruce.

(2018). A queda do céu - palavras de um xamã yanomami. São Paulo: Companhia das Letras.

KRENAK, Ailton.

(2019). Ideias para adiar o fim do mundo. São Paulo: Companhia das Letras.

(2000). O lugar onde a terra descansa. Rio de Janeiro, Eco Rio; Núcleo de Cultura Indígena.

KUSH, Rodolfo.

(1989). América Profunda. Buenos Aires: Ed. Hachette.

LEFEBVRE, Henri.

(2011). O direito à Cidade. 5. ed. São Paulo: Centauro.

LISB0A, João Francisco Kleba.

(2018). Entre armadilhas e atalhos: acadêmicos e artistas indígenas no contexto interétnico de Roraima. Iluminuras. Porto Alegre, v. 19, n. 46. p. 40-62.

LUCIANO, Gersem dos Santos.

(2006). O Índio Brasileiro: o que você precisa saber sobre os povos indígenas no Brasil de hoje. Brasília: Ministério da Educação, Secretaria de Educação Continuada, Alfabetização e Diversidade; LACED/Museu Nacional.

MAXAKALI, Sueli; MAXAKALI, Isael.

(2019). Yãmiyhex - As mulheres espíritos. Premio Carlos Reichenbach. Filme. Brasil, cor, $77 \min$.

MUNDURUKU, Daniel.

(2000). 0 Banquete dos Deuses - conversa sobre a origem e a cultura brasileira. São Paulo: Global Editora.

OLIVEIRA, João Pacheco de (Org.).

(1998a). Indigenismo e Territorialização Poderes, rotinas e saberes coloniais no Brasil contemporâneo. Rio de Janeiro: Contra Capa.

(1998b). Uma etnologia dos "índios misturados"? Situação colonial, territorialização e fluxos culturais. Mana, v. 4, n. 1. Rio de Janeiro. p. 47-77.
OLIVEIRA, Luiz Sérgio.

(2012). A mundanidade da arte. ARS(São Paulo), ano 10, n.20.

PARÁ YXAPY, Patrícia Ferreira.

(2019). Carta de uma mulher guarani em busca da terra sem mal. Festival de Cinema de Berlim. Filme, Brasil, 80min.

PEDROSA, Mário.

(1981). Arte Ambiental, arte pós-moderna, Hélio Oiticica. In: AMARAL, Aracy Abreu (org.). Dos murais de Portinariaos espaços de Brasília. São Paulo: Perspectiva.

PINHEIRO, Sophia.

(2017). Jaexá Va'e Jo Hete Re: "0 corpo que enxergamos". Ensaio Fotográfico. Iluminuras. v. 18, n. 43. Porto Alegre. p. 361-367

PORTO-GONÇALVES, Carlos Walter.

(2006). Verbete Abya Yala. In: SADER, Emir. (org.). Enciclopédia Contemporânea da América Latina e do Caribe. São Paulo: Boitempo.

POTIGUARA, Eliane.

(2018). Metade cara, metade máscara. Lorena, Uk'a Editorial.

RIBEIR0, Marilia Andrés.

(1998). Arte e Política no Brasil: a atuação das neovanguardas nos anos 60. In: FABRIS, Annateresa; COSTA, Cacilda Teixeira da.(org). Arte \& Política - algumas possibilidades de leitura. Belo Horizonte: C/Arte; FAPESP.

SAMPAI0, 0sias Awá-Mboparadjú Guarani Ramos (2017). A universidade como área de influência, no olhar de um Guarani. Iluminuras, v.18, n.43. p-134-157.

SANTOS, Boaventura de Sousa.

(2019). O fim do império cognitivo: a afirmação das epistemologias do sul. Belo Horizonte: Autêntica Editora.

SANTOS, Boaventura de Sousa; CUSICANQUI, Silvia Rivera.

(2013). Conversación del Mundo. Valle de las Animas, La Paz, Bolívia. Entrevista. Projeto Alice - Centro de Estudos Sociais/CES. Universidade de Coimbra. Disponível em: 
<https://www.youtube.com/watch?v=xjgHfSr LnpU> Acesso em: 31 jan. 2020.

SOUZA, Solange Jobim; KRAMER, Sonia.

(2009). Política, cidade, educação: itinerários de Walter Benjamin. Rio de Janeiro: Contraponto, Ed. PUC-Rio.

SOUZA LIMA, Antonio Carlos de.

(1987). Sobre indigenismo, autoritarismo e nacionalidade: Considerações sobre a constituição do discurso e da prática da proteção fraternal no Brasil. In: OLIVEIRA, João Pacheco de (0rg.) Sociedades Indígenas $e$ Indigenismo no Brasil. Rio de Janeiro, UFRJ/Ed. Marco Zero. p. 149-204.

SOUZA LIMA, Antônio Carlos de; BARROSO, Maria Macedo (Orgs.).

(2018). O projeto trilhas de conhecimentos e $O$ ensino superior de indígenas no Brasil: uma experiência de fomento e investigação para ações afirmativas. Rio de Janeiro: E-papers.

TABAJARA, Auritha.

(2018). Coração na aldeia, pés no mundo. Xilogravuras de Regina Drozina. Lorena, Uk'a Editorial.

TAUSSIG, Michael.

(1993). Xamanismo, Colonialismo e o Homem Selvagem: um estudo sobre o terror e a cura. São Paulo: Paz e Terra.
TODOROV, Tzevetan.

(1993). Nós e os Outros: a reflexão francesa sobre a diversidade humana. Rio de Janeiro: Jorge Zahar.

VIVEIROS DE CASTRO, Eduardo.

(1996). Os pronomes cosmológicos e o perspectivismo ameríndio. Mana, vol. 2, n. 2. Rio de Janeiro. p. 115-144.

WARBURG, Aby.

(2015). Histórias de fantasmas para gente grande, escritos, esboços e conferências. São Paulo: Companhia das Letras.

WILLS, Wirt Henry

(2012). On the trail of the lonesome pine: archaeological paradigms and the chaco "Tree of Life". American Antiquity. JSTOR, vol. 77, n. 3, p. 478-497. Disponivel em: www.jstor.org/stable/23486285. Acesso em: 10 jan. 2019.

\section{Recebido em}

março de 2020

\section{Aprovado em}

novembro de 2020 